\title{
Multiplicity of enzymatic functions in the CAZy AA3 family
}

\author{
Leander Sützl ${ }^{1,2} \cdot$ Christophe V. F. P. Laurent $^{1,2} \cdot$ Annabelle T. Abrera ${ }^{1,3} \cdot$ Georg Schütz $^{1,2} \cdot$ Roland Ludwig $^{1,2}$. \\ Dietmar Haltrich ${ }^{1,2}$ (D)
}

Received: 4 December 2017 / Revised: 12 January 2018 / Accepted: 14 January 2018 / Published online: 6 February 2018

(C) The Author(s) 2018. This article is an open access publication

\begin{abstract}
The CAZy auxiliary activity family 3 (AA3) comprises enzymes from the glucose-methanol-choline (GMC) family of oxidoreductases, which assist the activity of other AA family enzymes via their reaction products or support the action of glycoside hydrolases in lignocellulose degradation. The AA3 family is further divided into four subfamilies, which include cellobiose dehydrogenase, glucose oxidoreductases, aryl-alcohol oxidase, alcohol (methanol) oxidase, and pyranose oxidoreductases. These different enzymes catalyze a wide variety of redox reactions with respect to substrates and co-substrates. The common feature of AA3 family members is the formation of key metabolites such as $\mathrm{H}_{2} \mathrm{O}_{2}$ or hydroquinones, which are required by other AA enzymes. The multiplicity of enzymatic functions in the AA3 family is reflected by the multigenicity of AA3 genes in fungi, which also depends on their lifestyle. We provide an overview of the phylogenetic, molecular, and catalytic properties of AA3 enzymes and discuss their interactions with other carbohydrate-active enzymes.
\end{abstract}

Keywords Cellobiose dehydrogenase $\cdot$ Glucose oxidase $\cdot$ Aryl-alcohol oxidase $\cdot$ Methanol oxidase $\cdot$ Pyranose oxidase $\cdot$ Glucose dehydrogenase $\cdot$ Lignocellulose degradation

\section{Introduction}

The Carbohydrate-Active enZYme (CAZy) database (http:// www.cazy.org/) describes families of structurally related catalytic modules and domains of enzymes that degrade, modify, or create glycosidic linkages. The classification system in this database is founded on amino acid sequence similarities, protein folds, and catalytic mechanisms. The catalytic modules or enzymes in this database are grouped in families of glycoside hydrolases (GH), polysaccharide lyases (PL), carbohydrate esterases (CE), and glycosyltransferases (GT); in addition, the non-catalytic carbohydrate-binding

Dietmar Haltrich

dietmar.haltrich@boku.ac.at

1 Food Biotechnology Laboratory, Department of Food Science and Technology, BOKU—University of Natural Resources and Life Sciences Vienna, Muthgasse 11, A-1190 Wien, Austria

2 Doctoral Programme BioToP_Biomolecular Technology of Proteins, BOKU-University of Natural Resources and Life Sciences Vienna, Muthgasse 18, A-1190 Wien, Austria

3 University of the Philippines Los Baños, College Laguna, Los Baños, Philippines modules (CBM) associated with these catalytic modules are included in the database as well (Lombard et al. 2014).

It is now understood that the main chains of polysaccharides such as chitin, cellulose, or starch are not only cleaved by hydrolytic mechanisms but also by oxidative reactions catalyzed by lytic polysaccharide monooxygenases (LPMO; (Beeson et al. 2015)). Because of this and the intimate link between plant cell wall polysaccharides and lignin — and thus the necessity to degrade lignin as well to achieve efficient cell wall deconstruction - the curators of the CAZy database recently added a new enzyme class, termed "Auxiliary Activities" (AA), which comprises redox enzymes that act in conjunction with CAZymes. These auxiliary activities include for example the abovementioned LPMOs (families AA9, AA10, AA11, and AA13) as well as redox enzymes involved in lignin breakdown, with the latter comprising well-studied laccases (AA1) or lignin-active class-II peroxidases (AA2) (Levasseur et al. 2013). A large and varying group of auxiliary activities is represented by family AA3. All of its members belong to the glucose-methanol-choline (GMC) family of oxidoreductases (Cavener 1992) and depend on a flavin-adenine dinucleotide (FAD) cofactor for their activity. Some AA3 members are very well characterized both from enzymological and structural view; yet overall, this 
group is still functionally enigmatic, with possible functions of some of its members in, e.g., lignocellulose degradation emerging only slowly (Kracher et al. 2016).

A comparison based on a phylogenetic inference using sequences of 58 biochemically characterized enzymes (Fig. 1) shows that family AA3 is further divided into four subfamilies: AA3_1 (including the flavodehydrogenase domains of cellobiose dehydrogenase, $\mathrm{CDH}$ ), AA3_2 (aryl-alcohol oxidoreductases, both oxidases, AAO and dehydrogenases, AADH, and glucose 1-oxidases, GOx; here we also included glucose 1-dehydrogenases, GDH, and pyranose dehydrogenases, $\mathrm{PDH}$, based on their high-sequence similarities to the former two enzymes), AA3_3 (alcohol oxidases; AOx), and AA3 4 (pyranose oxidases, $\mathrm{POx}$ ).

A flavin-dependent enzyme of the GMC family is typical composed of a flavin-binding domain comprising the N-terminal, the C-terminal and an internal region of the sequence, and a substrate-binding domain comprising two internal, discontinuous regions of the sequence (Cavener 1992; Kiess et al. 1998). Some GMC family members may contain structurally distinct loops or even additional domains (Fig. 2). The flavin-binding domain is highly conserved in all members of the GMC family and shows the canonical Rossmann fold or $\beta \alpha \beta$ mononucleotide-binding motif, interacting with the ADP moiety of FAD. The sequence and structure of the substratebinding domain of GMC oxidoreductases are less preserved, which reflects the diversity in substrate specificity within this family. Even though the substrates (various carbohydrates or alcohols) oxidized by these GMC oxidoreductases are diverse, the overall reaction mechanism of the FAD-dependent enzymes is similar. The substrate oxidation involves a direct hydride transfer from the substrate to the N5 atom of the isoalloxazine moiety of FAD, resulting in reduced $\mathrm{FADH}_{2}$ (reductive half-reaction). $\mathrm{FADH}_{2}$ is subsequently re-oxidized (oxidative half-reaction) by either oxygen (resulting in the formation of hydrogen peroxide) or by alternative electron acceptors such as different quinones or (complexed) metal ions (resulting in the corresponding hydroquinones or reduced metal ions).

Putative genes encoding members of the AA3 family are predominantly found in fungal organisms, both ascomycetes and basidiomycetes, but they are also found in insects such as Drosophila melanogaster or Bombyx mori where they are thought to play a role in immunity and development (Iida et al. 2007; Sun et al. 2012). Often multiple genes of members of a certain subfamily are found in one species, albeit this multiplicity of genes shows considerable discrepancies among the different AA3 subfamilies as was shown by an analysis of 41 fungal genomes (Levasseur et al. 2013). Multigenicity is most pronounced in the AA3_2 subfamily, with for example 22 putative AA3_2 genes found in Coprinopsis cinerea (GOx and AAO only, (Levasseur et al. 2013), 26 putative AA3_2 genes in Aspergillus niger CBS
513.88 , or a total of 31 AA3 genes in Stereum hirsutum (Kracher et al. 2016). Multigenicity is less pronounced in subfamilies AA3_3 and AA3_4, with up to seven putative AA3_3 genes in Stereum hirsutum or a maximum number of three AA3 4 genes in Auricularia delicata, again based on the comparison of 41 fungal genomes (Levasseur et al. 2013). Multigenicity is least pronounced in subfamily AA3_1. Genes of this subfamily are found in higher numbers in ascomycetes (averaging $\sim 2.3$ copies in 13 ascomycetes genomes), with a maximum number of four genes in Botrytis cinerea, whereas $\sim 0.6$ copies were detected in the genomes of 28 basidiomycete species, which typically showed only a single copy of this AA3 1 gene when present. It should be pointed out that the majority of these genes are putatively assigned, and that most of the respective gene products have not been studied biochemically, e.g., with resect to their actual substrates. According to the CAZy website (http://www.cazy.org/AA3_characterized.html, accessed on Dec. 3, 2017) only 37 AA3 member proteins have been characterized biochemically.

\section{Subfamily AA3_1—cellobiose dehydrogenase}

The first subfamily of the AA3 family consists of cellobiose dehydrogenases (CDH; EC 1.1.99.18, cellobiose:acceptor 1oxidoreductase) (Levasseur et al. 2013), which are to date the only known extracellular hemoflavoproteins (Zamocky et al. 2006). CDH was first discovered and described by Eriksson and co-workers while analyzing the secretomes of the whiterot fungi Trametes versicolor and Phanerochaete chrysosporium in the presence of cellulosic substrates (Westermark and Eriksson 1974).

The monomeric multi-domain glycoprotein $\mathrm{CDH}$ harbors a haem $b$ and an FAD cofactor, which are found in the Nterminal cytochrome $\left(\mathrm{CYT}_{\mathrm{CDH}}\right)$ and the $\mathrm{C}$-terminal dehydrogenase $\left(\mathrm{DH}_{\mathrm{CDH}}\right)$ domain, respectively (Tan et al. 2015; Zamocky et al. 2006). The CYT domain with its haem $b$ has also been classified as a separate auxiliary activity in the CAZy database, AA8 of iron reductases (Levasseur et al. 2013). The two domains of CDH are connected by a papainsensitive flexible linker of approx. 20-35 amino acids (average of $28 \pm 7$ amino acids deduced from $293 \mathrm{CDH}$ sequences), which imparts significant mobility to the individual CDH domains and allows an open (Fig. 2a) and a closed (Fig. 2b) conformation of CDH (Henriksson et al. 1991; Tan et al. 2015). Structures of the separate domains of P. chrysosporium $\mathrm{CDH}(P c \mathrm{CDH})$ were published in the early 2000s (CYT $\mathrm{CDH}_{\mathrm{CH}}: 1.9 \AA$, PDB 1D7C, (Hallberg et al. 2000); $\mathrm{DH}_{\mathrm{CDH}}: 1.5 \AA$, PDB 1KDG, (Hallberg et al. 2002)), while structures of intact $\mathrm{CDH}$ were published only recently (Neurospora crassa CDH IIA: $2.9 \AA$ A, PDB 4QI7; Myriococcum thermophilum CDH: $3.2 \AA$, PDB 4QI6), due to the difficulties in obtaining suitable crystals of the flexible 


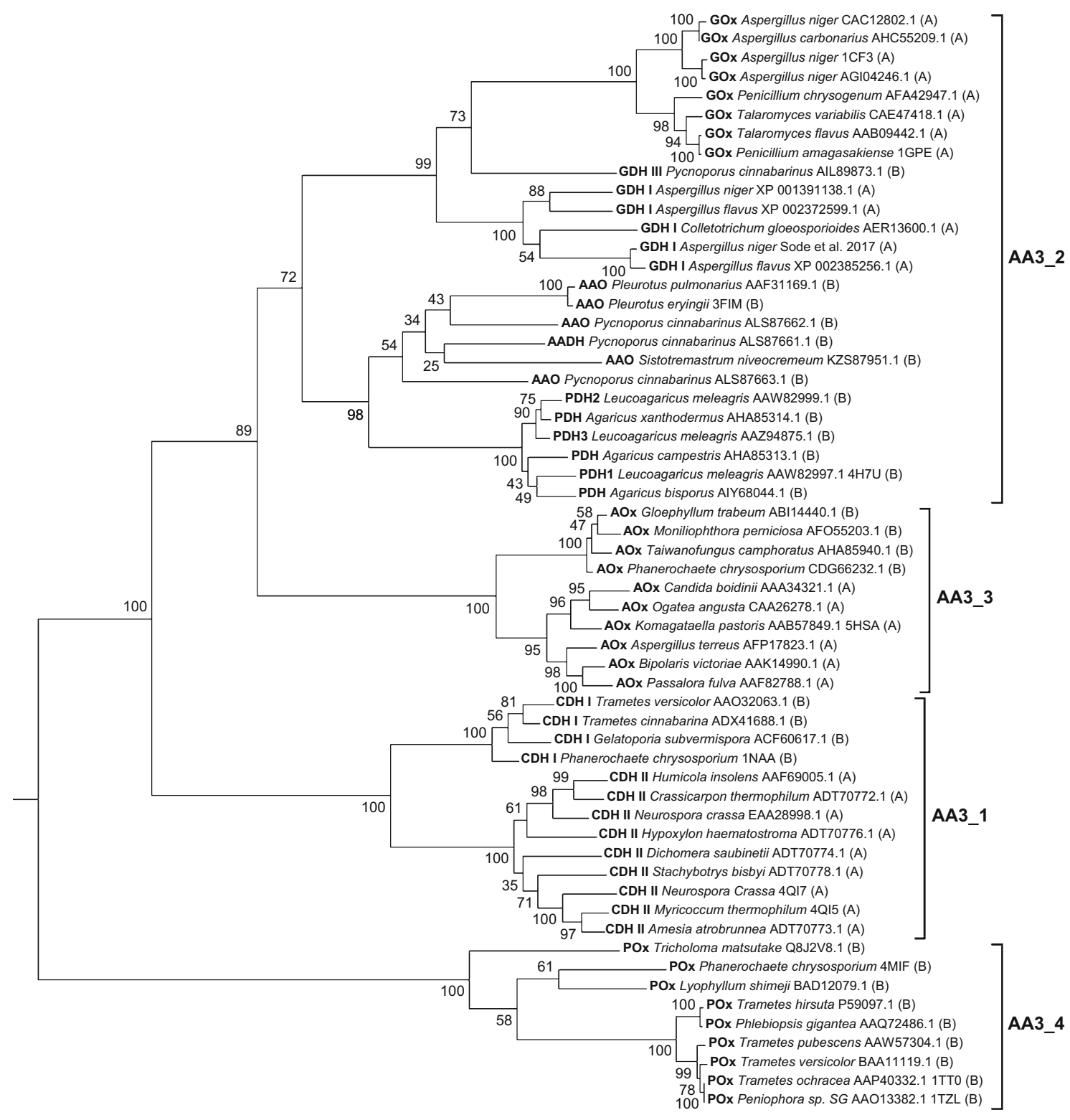

Fig. 1 Phylogeny of the AA3 family of fungal GMC oxidoreductases. The phylogenetic tree was calculated using sequences of 58 experimentally characterized enzymes, aryl-alcohol oxidase (AAO), aryl-alcohol dehydrogenase (AADH), alcohol oxidase (AOx), cellobiose dehydrogenase flavodehydrogenase domain $(\mathrm{CDH}$, class $\mathrm{I}+\mathrm{II})$, glucose dehydrogenase (GDH, class I + III), glucose oxidase (GOx), pyranose dehydrogenase $(\mathrm{PDH})$, and pyranose oxidase (POx) of fungal origin belonging to the phylum of ascomycetes (A) or basidiomycetes (B).

proteins (Tan et al. 2015). Harada et al. recently confirmed the domain movement by using atomic force microscopy (Harada et al. 2017). This conformational change and the mobility of the two domains are of particular importance for the electron transfer chain described below.

CDHs can be divided into three classes (Fig. 3), namely class-I, class-II, and class-III (Harreither et al. 2011; Zamocky et al. 2004, 2008). This division is based on phylogenetic
Sequence descriptions include species names, NCBI version numbers, and PDB codes if available. Sequences were aligned using M-coffee (Wallace et al. 2006) with default settings. Phylogeny was inferred using PhyML (Guindon et al. 2010) and the Whelan and Goldman (WAG) amino acid substitution model (Whelan and Goldman 2001). Branch support was calculated by 500 bootstrap repetitions (values displayed in percent). The tree was visualized in MEGA7 (Kumar et al. 2016) and rooted on midpoint

analyses where basidiomycete $\mathrm{CDHs}$ are regrouped in classI and ascomycete CDHs can be found both in class-II and class-III. Genes of the third class are found in ascomycetes and have yet to be characterized. CDHs of class-II can further be grouped into subclasses $\mathrm{A}$ and $\mathrm{B}$, depending on whether CDH bears a C-terminal type- 1 carbohydrate-binding module (CBM1), allowing the enzyme to bind firmly to cellulose or not. Class-I and class-IIB CDHs lack a CBM1; class-I CDHs 
a
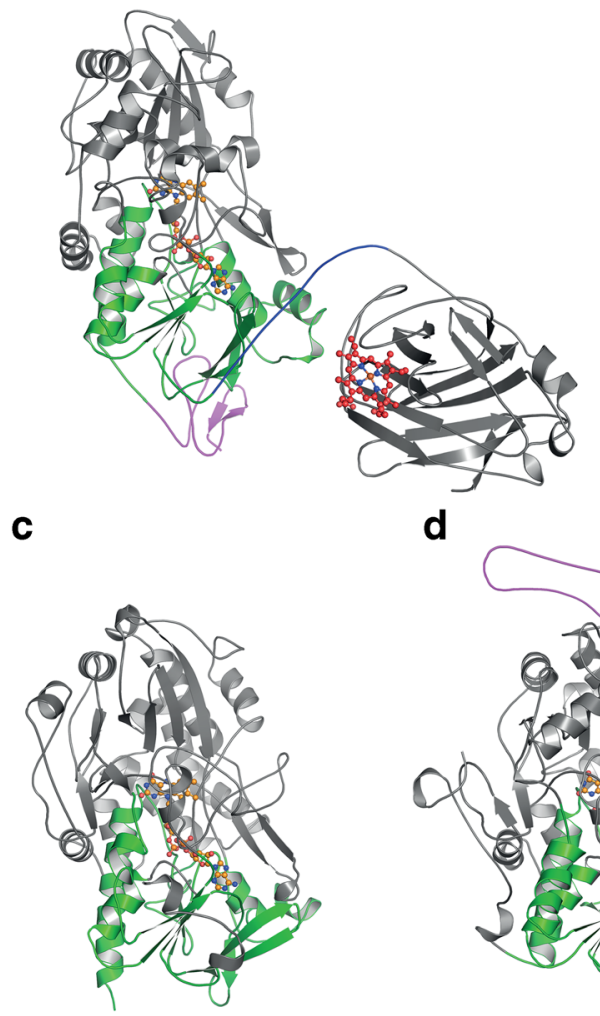

Fig. 2 Molecular structures of representative members of the AA3 families in cartoon representation. a Neurospora crassa cellobiose dehydrogenase CDH IIA in the open conformation (PDB 4QI7 (Tan et al. 2015)), b Myricoccum thermophilum cellobiose dehydrogenase in the closed conformation (PDB 4QI6 (Tan et al. 2015)), c subunit of homodimeric Aspergillus niger glucose oxidase GOx1 (PDB 1CF3 (Wohlfahrt et al. 1999)), d subunit of homo-octameric Pichia pastoris alcohol oxidase AOx1 (PDB 5HSA (Koch et al. 2016)) and e subunit of homo-
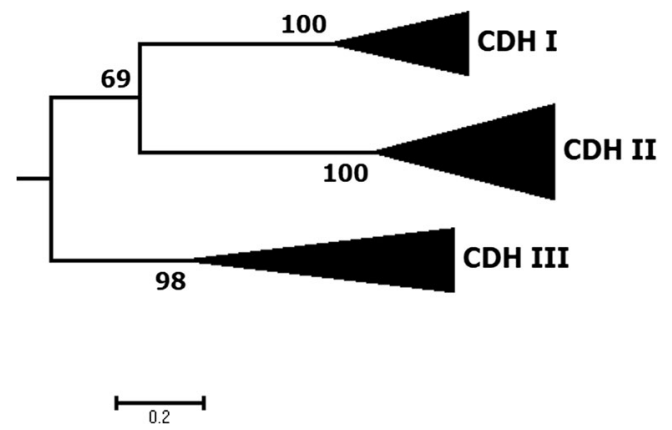

Fig. 3 Phylogeny of cellobiose dehydrogenase (CDH); AA3_1 genes form three well-supported classes with distinct molecular and catalytic properties. The phylogenetic subtree was calculated using the flavin domains of $21 \mathrm{CDH}$ sequences representative for CDH class I (6 sequences, 4 characterized), class II (9 sequences, 9 characterized), and class III (6 sequences, 0 characterized). The tree was rooted within AA3 family enzymes (not shown). Sequences were aligned using M-coffee (Wallace et al. 2006) with default settings. Phylogeny was inferred using PhyML (Guindon et al. 2010) and the Whelan and Goldman (WAG) amino acid substitution model (Whelan and Goldman 2001). Branch support was calculated by 100 bootstrap repetitions (values displayed in percent). The tree was visualized in MEGA7 (Kumar et al. 2016)

\section{b}
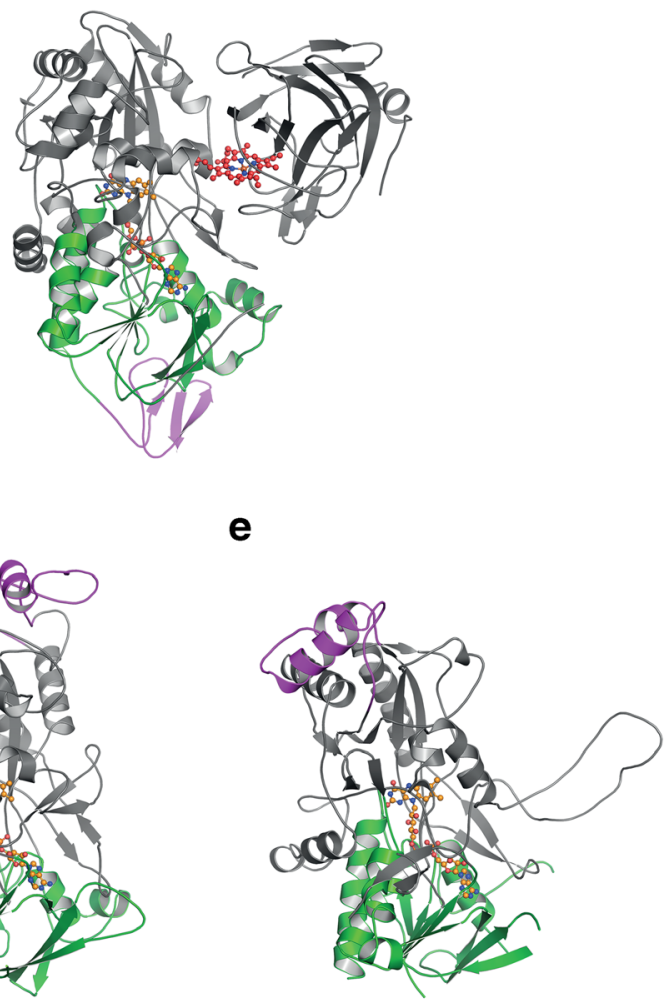

tetrameric Phanerochaete chrysosporium pyranose oxidase (PDB 4MIF (Hassan et al. 2013)). The FAD-binding domain is highlighted in green; FAD is shown in orange (ball-and-stick representation), and the haem $b$ in the cytochrome domain of $\mathrm{CDH}$ is depicted in red (ball-and-stick representation). The carbohydrate-binding module (CBM1) of the two CDHs (a, b), the insertion loop of PpAOx1 (d) and the head domain of PcPOx (e) are shown in magenta can nevertheless strongly bind to cellulose by a yet unknown mechanism (Zamocky et al. 2006).

CDHs oxidize cellobiose, cellodextrins, or structurally related oligosaccharides such as lactose at $\mathrm{C}-1$ of the reducing end. Cellobiose is thus oxidized to cellobionolactone (which then spontaneously hydrolyses to cellobionate) while the FAD cofactor is reduced to $\mathrm{FADH}_{2}$ (Hyde and Wood 1997). Other hemicellulose- and starch-derived oligosaccharides, such as xylo-, manno-, or malto-oligosaccharides are oxidized by a number of CDHs as well, albeit with lower catalytic efficiencies. CDHs typically discriminate monosaccharides and show lowcatalytic efficiency towards glucose, galactose, and mannose (Zamocky et al. 2006), for example, the specificity constant $k_{\text {cat }} \cdot K_{\mathrm{M}}{ }^{-1}$ of $P c \mathrm{CDH}$ for cellobiose and glucose are $150 \times 10^{3} \mathrm{M}^{-1} \mathrm{~s}^{-1}$ and $0.015 \times 10^{3} \mathrm{M}^{-1} \mathrm{~s}^{-1}$, respectively (Kracher and Ludwig 2016). The carbohydrate substratebinding site is located in the $\mathrm{DH}_{\mathrm{CDH}}$ domain close to the isoalloxazine moiety of FAD, which is accessible through a 12-Å long tunnel (Hallberg et al. 2002). This binding site can also be accessed by the sugar substrates in the closed 
conformation of CDH (Tan et al. 2015). As a result of the reductive half-reaction, the two electrons that are taken up in the $\mathrm{DH}_{\mathrm{CDH}}$ domain can subsequently be transferred to either a two-electron acceptor (e.g., 2,6-dichloro-indophenol (DCIP), which is routinely used in activity assays) or a one-electron acceptor (e.g., the haem $b$ group in the $\mathrm{CYT}_{\mathrm{CDH}}$ in an interdomain electron transfer) (Zamocky et al. 2006). Although this oxidative half-reaction can be achieved by a myriad of small molecular electron acceptors, it is the interdomain electron transfer from the $\mathrm{DH}_{\mathrm{CDH}} \mathrm{FADH}_{2}$ to the low redox potential $\mathrm{CYT}_{\mathrm{CDH}}$ haem $b$ that has been of particular interest over the past few years (Harada et al. 2017; Kadek et al. 2017; Kracher et al. 2016). In order to complete the electron transfer chain described above, the reduced haem $b$ can in turn reduce a terminal electron acceptor such as copperdependent LPMOs (Kracher et al. 2016; Phillips et al. 2011). Other electron acceptors of $\mathrm{CDH}$ that may be functionally important include variously (complexed) metal ions, most importantly $\mathrm{Fe}^{3+}$ or $\mathrm{Mn}^{3+}$ malonate (Ander 1994; Bao et al. 1993). CDH shows negligible activity with oxygen, even though it was originally termed cellobiose oxidase (Ayers et al. 1978). This reduction of metal ions at AA8 CYT $\mathrm{CDH}_{\mathrm{C}}$ could be involved, e.g., in the generation of highly reactive hydroxyl radicals $\left(\mathrm{OH}^{\prime}\right)$ via Fenton's reaction (see below). Interestingly, phylogenetically closely related AA8 domains were also found in a newly discovered group of fungal oxidoreductases that show a modular structure very similar to $\mathrm{CDH}$, pyrroloquinoline quinone or PQQ-dependent pyranose dehydrogenases. PQQ-dependent PDH (which as a quinohaemoprotein is both structurally and biochemically different from FAD-dependent pyranose dehydrogenase of subfamily AA3_2) is classified in a separate family in CAZy, auxiliary activity AA12 (Matsumura et al. 2014). So far, PQQ-dependent PDH has only been described and characterized from the fungus Coprinopsis cinerea (Takeda et al. 2015).

\section{Subfamily AA3_2-aryl-alcohol oxidase/dehydrogenase}

Aryl-alcohol oxidase (AAO; EC 1.1.3.7, aryl-alcohol:oxygen oxidoreductase) was first isolated and studied from different Pleurotus species (Bourbonnais and Paice 1988; Guillén et al. 1990; Sannia et al. 1991). AAOs are monomeric, two-domain enzymes containing non-covalently attached FAD, which are secreted by a number of wood-degrading fungi (Ferreira et al. 2015). The structure of AAO from Pleurotus eryngii (PeAAO; $2.55 \AA$, PDB 3FIM, (Fernández et al. 2009)) shows a funnel-shaped channel connecting the active-site with the solvent. Access to this channel is limited by three aromatic residues, which also interact both with the (hydrophobic) alcohol substrate and oxygen during access to the buried FAD group.
AAOs typically catalyze the oxidation of a primary alcohol group of a range of different aromatic and aliphatic unsaturated alcohols, many of which are either secreted by fungi or formed during fungal decomposition of lignocellulose, to the corresponding aldehydes. Concomitantly, oxygen is reduced to hydrogen peroxide. PeAAO is the best-studied AAO enzyme to date, both with respect to its structural and biochemical properties as well as its reaction mechanism (HernandezOrtega et al. 2012). PeAAO shows high activity and a highcatalytic efficiency of $5.23 \times 10^{6} \mathrm{M}^{-1} \mathrm{~s}^{-1}$ with $p$-anisyl alcohol. Other alcohols that serve as good electron donor substrates for PeAAO include veratryl alcohol, cinnamyl alcohol, or 2,4-hexadien-1-ol (Ferreira et al. 2006; Guillén et al. 1992).

A recent study of the Pycnoporus cinnabarinus genome together with secretome studies revealed four AA3 2 enzymes that are secreted during biomass degradation (Levasseur et al. 2014). One of these was identified as a glucose dehydrogenase; the other three showed high-sequence identities of $44.5-48.7 \%$ to PeAAO (Mathieu et al. 2016). The corresponding proteins were recombinantly produced in A. niger and biochemically characterized. They showed comparable activities to AAOs for their reductive half-reaction in oxidizing a range of aromatic alcohols with catalytic efficiencies for, e.g., $p$-anisyl alcohol ranging from $0.631 \times$ $10^{3} \mathrm{M}^{-1} \mathrm{~s}^{-1}$ to $16.9 \times 10^{3} \mathrm{M}^{-1} \mathrm{~s}^{-1} \cdot p$-Anisyl alcohol was also one of the preferred substrates of these three enzymes. The three isoforms, however, also differ significantly with respect to the reactivity with some of their electron donor substrates. $p$-Anisyl alcohol, for example, is oxidized by all three isoforms, where $m$-anisyl alcohol is only accepted by one of them with the other two showing negligible activity. While these three enzymes resemble AAO with respect to their alcohol substrates, one of these three enzymes did not show any activity with oxygen, and oxygen reactivity of the other two enzymes was low compared to the activity with alternative, quinoid electron acceptors such as $p$-benzoquinone or DCIP with relative dehydrogenase to oxidase activities of approx. 50:1 (Mathieu et al. 2016). Catalytic efficiencies for some of these electron acceptors were also very high, e.g., the enzyme termed $P c$ AAQO1 showed a $k_{\text {cat }} \cdot K_{\mathrm{M}}{ }^{-1}$ value of $0.877 \times$ $10^{6} \mathrm{M}^{-1} \mathrm{~s}^{-1}$ for the substrate $p$-benzoquinone (3-chlor- $p$ anisyl alcohol in saturating concentrations). In addition, these enzymes reduced phenoxy radicals that are formed by laccases during activity on lignin. Hence, these enzymes are no true oxidases but dehydrogenases, and they were termed aryl-alcohol quinone oxidoreductases (AAQO). It should be noted that the three $P$. cinnabarinus aaqo genes clustered with (biochemically characterized) AAO in a phylogenetic comparison (Mathieu et al. 2016). As with the electron donor substrates, reactivity of these AAQO isoforms of $P$. cinnabarinus differed considerably for different electron acceptor substrates as indicated by the catalytic efficiencies determined. The in vivo function of AAO had been suggested 
as a source of hydrogen peroxide for fungal peroxidases active on lignin. The occurrence of extracellular AAO-like enzymes that do not react with oxygen, or only very poorly do so, implicates that their role could go beyond the provision of $\mathrm{H}_{2} \mathrm{O}_{2}$.

\section{Subfamily AA3_2-glucose oxidase and glucose dehydrogenase}

Two different FAD-dependent enzymes are found in AA3 2, which specifically oxidize $\beta$-D-glucose (Glc) at the anomeric carbon to $\delta$-gluconolactone (D-glucono-1,5-lactone), glucose 1-oxidase (GOx), and glucose 1-dehydrogenase (GDH). GOx and GDH are catalytically and phylogenetically closely related (Fig. 4), but differ in their preference for the electron acceptors employed in their oxidative half-reactions. While GOx preferentially reduces molecular oxygen to $\mathrm{H}_{2} \mathrm{O}_{2}$, GDH shows very low activity with $\mathrm{O}_{2}$ and utilizes a range of alternative electron acceptors.

GDH was not included in the original description of subfamily AA3_2 (Levasseur et al. 2013). Mori et al. (2011) showed for the first time that GOx and GDH cluster in distinct phylogenetic clades. A more detailed phylogenetic analysis of fungal GOx and GDH sequences performed by us revealed four distinct phylogenetic clades. Oxidases are only found in one of the four clades while the other three contain only dehydrogenases and uncharacterized enzymes. We propose to name these four clades GOx and GDH class-I to III. The GOx clade contains only ascomycete sequences including all glucose 1-oxidases characterized to date, GDH class-I comprises only ascomycete sequences including most of the currently characterized glucose 1-dehydrogenases, GDH class-II includes only ascomycete sequences that are completely uncharacterized to date, and GDH class-III comprises only basidiomycete sequences (with only one characterized member to date, see below). An interesting aspect of this analysis is the phylogenetic relationship between ascomycete GOx and basidiomycete GDH class-III, which is closer than that of GOx with other ascomycete GDH sequences. This, together with the longbranch length of GOx ( 0.8 substitutions per site) compared to GDH clades, indicates a high degree of specialization already from an early point in GOx/GDH evolution. In the past, enzymes of various organisms were often falsely annotated as GOx, leading to the belief that GOx is much more widely distributed among fungi than is actually the case. Later on, these falsely annotated GOx were often found to be GDH or POx instead. This wrong annotation can be easily explained by the high-sequence similarity in the case of $\mathrm{GDH}$, and the utilization of the same substrates (glucose and $\mathrm{O}_{2}$ ) in the case of POx.

GOx (EC 1.1.3.4, $\beta$-D-glucose:oxygen 1-oxidoreductase) is a homo-dimeric glycoprotein with a non-covalently but tightly bound FAD cofactor. The first description of GOx from

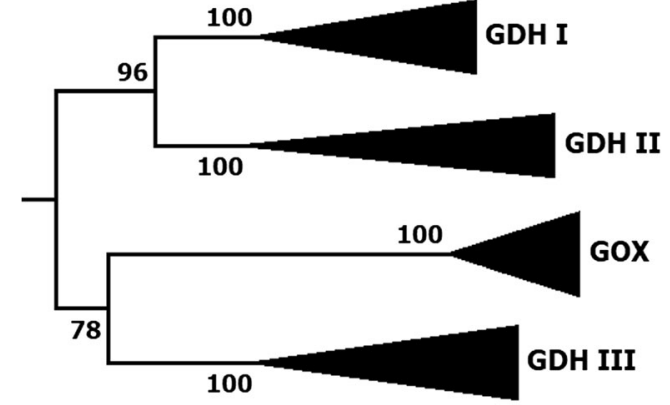

$\longmapsto 0.2 \longrightarrow$

Fig. 4 Detailed phylogeny of glucose oxidases and glucose dehydrogenases showing the newly proposed classification. An extended BLAST search resulted in numerous putative glucose oxidoreductases. The tree shown here was calculated using $28 \mathrm{GOx}$ and GDH sequences representative for the clades GOx ( 8 sequences, 8 characterized), GDH class-I (7 sequences, 5 characterized), GDH classII (6 sequences, 0 characterized), and GDH class-III (7 sequences, 1 characterized). The tree was rooted within AA3 family enzymes (not shown). Sequences were aligned using M-coffee (Wallace et al. 2006) with default settings. Phylogeny was inferred using PhyML (Guindon et al. 2010) and the Whelan and Goldman (WAG) amino acid substitution model (Whelan and Goldman 2001). Branch support was calculated by 100 bootstrap repetitions (values displayed in percent). The tree was visualized in MEGA 7 (Kumar et al. 2016)

A. niger (AnGOx) dates back to 1928 (Müller 1928). AnGOx also was the first AA3 enzyme, of which the crystal structure was solved in 1993 (2.3 $\AA$, PDB 1GAL (Hecht et al. 1993)). High-resolution structures of $A n \mathrm{GOx}(1.9 \AA$, PDB 1CF3) and GOx of Penicillium amagasakiense (1.8 A, PDB 1GPE) were published soon after (Wohlfahrt et al. 1999). GOx shows a very high preference for $\beta$-D-glucose, and hardly any other sugars are oxidized with significant catalytic efficiency. This specificity towards $\beta$-D-glucose stems from a highly specialized active-site architecture, characterized by the conserved residues Tyr, Thr or Ser, Arg, Asn, and the catalytic His pair (Y68, T110, R512, N514, H516, and H559 in AnGOx 1CF3), resulting in the formation of hydrogen bonds to all five hydroxyl groups of $\beta$-D-glucose (Wohlfahrt et al. 1999; Yoshida et al. 2015). The $\mathrm{C}-6$ hydroxyl group of $\beta$-D-glucose interacts with the conserved Thr or Ser, making GOx specifically selective over D-xylose (Sode et al. 2017). AnGOx is the currently best-characterized GOx and is also most widely used in industrial applications. AnGOx shows a catalytic efficiency of up to $1.5 \times 10^{6} \mathrm{M}^{-1} \mathrm{~s}^{-1}$ for D-glucose (Roth and Klinman 2003) and was once described as the "Ferrari" among flavin-dependent oxidases (Mattevi 2006).

Even though the first fungal glucose 1-dehydrogenase (GDH; EC 1.1.5.9 transferred in 2013 from 1.1.99.10, Dglucose:quinone 1-oxidoreductase) was already reported in 1937 in Aspergillus (Ogura and Nagahisa 1937), attention towards GDH developed only lately for its possible application in glucose biosensors independent of $\mathrm{O}_{2}$ levels. The first 
crystal structure of Aspergillus flavus GDH was solved recently (AfGDH; $1.78 \AA \AA$, PDB 4YNT (Yoshida et al. 2015) and published together with a structure including the reaction product D-glucono-1,5-lactone (1.57 $\AA$, PDB 4YNU), showing specific substrate-binding interactions. GDHs are found either as monomeric or homodimeric proteins. They are phylogenetically and structurally very closely related to GOx, showing both the same domain architecture and conserved catalytic residues. This conformational relatedness is also reflected in the root-mean-square deviation (rmsd) value for the backbone $\mathrm{C} \alpha$ atoms between $A f G D H$ (4YNU) and $A n G O x$ (1CF3) of $1.31 \AA$. Together with structural features, GDH shares most of the active site composition and therefore the high-substrate specificity towards Glc with GOx, which typically is the preferred sugar substrate. Yet some GDHs show significant activity with D-xylose (Xyl), which can range from $2 \%$ relative activity of that with Glc to approximately equal activities for Glc and Xyl, depending on the source of the enzyme. This loss in specificity is attributed to a missing Thr or Ser, otherwise forming a hydrogen bond to the C-6 hydroxyl group of $\beta$-D-glucose (Sode et al. 2017). In contrast to GOx, GDH occurs both in ascomycota $(\mathrm{GDH}$ class-I and II) and basidiomycota (GDH class-III). To date only one class-III GDH from the basidiomycete $P$. cinnabarinus $(P c \mathrm{GDH})$ was characterized, which showed lower catalytic efficiency towards glucose than ascomycete GDH (Piumi et al. 2014). PcGDH does not show the complete set of highly conserved residues responsible for glucose binding in both GDH and GOx (only Y64, H528, and H571 are conserved), yet D-glucose is by far the preferred substrate (Piumi et al. 2014). Detailed kinetic studies of GDHs are still scarce; the catalytic activity was determined for example for Glomerella cingulata class-I GDH (GcGDH; $24.5 \times$ $10^{3} \mathrm{M}^{-1} \mathrm{~s}^{-1}$, D-glucose, and the ferrocenium ion as substrates; (Sygmund et al. 2011)) or for class-III PcGDH $\left(67 \mathrm{M}^{-1} \mathrm{~s}^{-1}\right.$ with D-glucose and DCIP as substrates; (Piumi et al. 2014)). GDH shows almost no reactivity with oxygen. Typical electron acceptors that are employed to re-oxidize its FAD include a range of differently substituted quinones or certain radicals such as phenoxy radicals.

\section{Subfamily AA3_2-pyranose dehydrogenase}

Pyranose dehydrogenase (PDH; EC 1.1.99.29, pyranose:acceptor oxidoreductase) was first isolated and described from Agaricus bisporus (Volc et al. 1997). PDH is an extracellular, monomeric, glycosylated enzyme that is found in a rather restricted group of litter-degrading basidiomycetes belonging to the Agaricaceae and Lycoperdaceae, but not in white-rot wood-decaying fungi (Volc et al. 2001). The structure of PDH1 from Leucoagaricus (Agaricus) meleagris (LmPDH1; $1.6 \AA$, PDB 4H7U, (Tan et al. 2013)) shows the typical two-domain architecture of the other AA3s, with a substrate- and a flavin-binding domain. In contrast to most other AA3s, FAD is covalently tethered to a His residue in the active site. The GMC family member structurally most similar to $L m \mathrm{PDH}$ is $P e \mathrm{AAO}$ with an rmsd value of $1.6 \AA$ for 544 of 575 aligned $\mathrm{C} \alpha$ atom pairs, as well as $A n \mathrm{GOx}$ with an rmsd value of $1.5 \AA$ for 461 aligned $\mathrm{C} \alpha$ atom pairs (Tan et al. 2013), as also reflected in the close phylogenetic relationship of these three branches of subfamily AA3_2 (Fig. 1). The access to the active site of PDH is rather open and unobstructed, which is also reflected in the enzyme's broad substrate reactivity, ranging from various mono- and oligosaccharides to even polysaccharides. Depending on the fungal source of the enzyme and the pyranose sugar substrate, $\mathrm{PDH}$ can catalyze the selective mono-oxidations at C-1, C-2, or C-3 of the sugar, or di-oxidations at $\mathrm{C}-2,3$ or $\mathrm{C}-3,4$ of the molecule, yielding the corresponding aldonolactones $(\mathrm{C}-1$ oxidation) or (di)ketosugars [(di)dehydrosugars or aldos(di)uloses] (Peterbauer and Volc 2010). LmPDH1, one of three isoforms of $\mathrm{PDH}$ from L. meleagris, is the biochemically and structurally best-studied representative of $\mathrm{PDH}$. Based on the catalytic efficiencies, L-arabinose (Ara), D-glucose, and D-galactose (Gal) are the preferred sugar substrates of $L m P D H 1\left(62.1 \times 10^{3} \mathrm{M}^{-1} \mathrm{~s}^{-1}, 57.5 \times 10^{3} \mathrm{M}^{-1} \mathrm{~s}^{-1}\right.$ and $46.2 \times 10^{3} \mathrm{M}^{-1} \mathrm{~s}^{-1}$, respectively). While Ara and Gal are only oxidized at $\mathrm{C}$-2, yielding the respective 2-keto sugars, Glc is oxidized both at C-2 and C-3, so that the final reaction product is 2,3-diketoglucose (Sygmund et al. 2008). As was shown by substrate turnover experiments and molecular dynamics simulations, oxidation at C-2 is preferred over C-3 oxidation (Graf et al. 2015). The reactivity of PDH with oxygen is negligible. PDH reduces a number of (complexed) metal ions (the ferrocenium ion, ferricyanide), variously substituted quinones (tetra-chloro-1,4-benzoquinone, 3,5,-di-t-butyl-1,2-benzoquinone) and the azino-bis-(3-ethylbenzthiazolin-6-sulfonic acid) (ABTS) cation radical, with the natural electron acceptor of PDH yet unknown (Kujawa et al. 2007). Three PDHencoding genes were identified in L. meleagris ( $p d h 1, p d h 2$, pdh3), coding for three PDH isoforms that share 75-92\% amino acid similarity. $p d h 2$ and $p d h 3$ are essentially transcribed constitutively, yet at very low levels, whereas $p d h 1$ expression is up-regulated upon exhaustion of the carbon source and appears to be additionally regulated under conditions of oxygen limitation (Kittl et al. 2008). A. bisporus contains only a single $p d h$ gene, which is expressed in the mycelium as well as the gills of the fruiting bodies, while expression is low in the stem and the hood of these fruiting bodies (Gonaus et al. 2016). In a comparison of the biochemical and kinetic properties of the three $L m P D H$ isoforms, it was shown that they possess comparable properties with respect to their electron donor sugar substrates (substrate specificity and kinetic properties). In contrast, their kinetic properties and relative activities differed significantly for model electron acceptor substrates studied, a radical (the ABTS cation radical), a 
quinone (benzoquinone), and a complexed iron ion (ferrocenium ion). Thus, a possible explanation for this multiplicity of PDH could be that in vivo the different PDH isoforms react preferentially with structurally different electron acceptors (Graf et al. 2017).

\section{Subfamily AA3_3-alcohol oxidase}

Alcohol oxidase (AOx, sometimes referred to as methanol oxidase, MOx, based on the preferred substrate of the enzyme; EC 1.1.3.13, alcohol:oxygen oxidoreductase) was first described in 1965 in the basidiomycete Polyporus obtusus (renamed to Spongipellis unicolor) (Janssen et al. 1965). AOx catalyzes the FAD-dependent oxidation of lower, aliphatic primary alcohols (both saturated and unsaturated) to the corresponding aldehydes. It is typically not active on secondary alcohols (Gvozdev et al. 2012).

FAD-dependent AOx is a key enzyme of methylotrophic yeasts that can utilize methanol (as well as other short primary alcohols) as sole source of carbon and energy. It has been primarily studied in these methylotrophic yeasts including Pichia, Candida, or Hansenula, where it is located in the peroxisomes, to which it is targeted by a C-terminal signal sequence (Ozimek et al. 2005). AOx can comprise up to $30 \%$ of the total cellular protein in these organisms. The structure of the alcohol oxidase AOX1 from Pichia pastoris $(P p \mathrm{AOx})$ has been solved both by crystallography and X-ray diffraction (2.35 A, PDB 5HSA, (Koch et al. 2016)) as well as by cryo-electron microscopy (3.4 $\AA$, PDB 5 I68 (Vonck et al. 2016)). PpAOx is a homo-octameric protein, with each subunit carrying one non-covalently attached FAD. This FAD is modified and contains an arabityl rather than the canonical ribityl chain attached to the isoalloxazine moiety, which is formed by an autocatalytic reaction. It is thought that this FAD modification affects the reactivity of the enzyme with its alcohol substrates primarily by lowing the Michaelis constant for methanol. The extent, to which the flavin is modified, is inversely correlated to the methanol concentration in the growth medium and may vary from 5 to $95 \%$ (Ashin and Trotsenko 1998). The preferred substrate of $P p A O x$ as judged from the catalytic efficiency is methanol $\left(9.58 \times 10^{3} \mathrm{M}^{-1} \mathrm{~s}^{-1}\right)$; $k_{\text {cat }} \cdot K_{\mathrm{M}}{ }^{-1}$ values decrease significantly with longer chain length of the alcohol substrates (Koch et al. 2016).

AOx from basidiomycete and/or phytopathogenic fungi has received significantly less attention compared to their yeast counterparts. An extracellular AOx isolated from cultures of the brown-rot fungus Gloeophyllum trabeum (GtAOx) displayed 50-53\% sequence identity to other yeast and fungal AOxs, including PpAOx (Daniel et al. 2007). Its C terminus is distinctly different from that of yeast $\mathrm{AOx}$, and it also contains no typical $\mathrm{N}$-terminal fungal signal sequence, yet immunofluorescence and TEM-immunogold labelling studies showed that GtAOx was extracellularly localized, associated with hyphal cell walls as well as with extracellular slime. GtAOx could not be shown in peroxisomes by TEMimmunogold labeling. The authors suggested that the Cterminal sequence of GtAOx is responsible for protein translocation (Daniel et al. 2007). In accordance with yeast AOx, GtAOx is a homo-octameric protein, with one non-modified and non-covalently attached FAD per subunit. Methanol is the preferred substrate of GtAOx, which is turned over at a catalytic efficiency $\left(6.78 \times 10^{3} \mathrm{M}^{-1} \mathrm{~s}^{-1}\right)$ comparable to that of PpAOx. Concomitantly, oxygen is reduced to hydrogen peroxide. In contrast to yeast AOx, which is believed to play a role in methanol metabolism and assimilation, it is thought that the role of GtAOx (or AOx from other fungal brownrotters) is to provide $\mathrm{H}_{2} \mathrm{O}_{2}$ for the fungal attack on lignocellulose. AOx is also found in the phytopathogenic basidiomycete Moniliophthora perniciosa, the causative agent of Witches' broom disease in the cocoa tree (Theobroma cacao). AOx is also secreted in M. perniciosa, but it was proposed to play a role in the utilization of methanol derived from the demethylation of pectin rather than in the attack on the plant (de Oliveira et al. 2012).

\section{Subfamily AA3_4-pyranose oxidase}

Pyranose oxidase (pyranose 2-oxidase, glucose 2-oxidase; POx, EC 1.1.3.10, pyranose:oxygen 2-oxidoreductase) is the most distantly related member of the AA3 family (Fig. 1) and does not show the otherwise high conservation of typical family motifs in the AA3 family. Therefore, it was rather late that POx was identified as a member of the GMC family (Albrecht and Lengauer 2003), even though POx was first described already in 1968 in the basidiomycete Spongipellis unicolor (Polyporus obtusus; (Janssen and Ruelius 1968). Crystal structures of Trametes ochracea (synonym Trametes multicolor) POx (ToPOx; $1.8 \AA$ A PB 1TT0; (Hallberg et al. 2004), Peniophora sp. POx (PsPOx, $2.35 \AA$, PDB 1TZL, (Bannwarth et al. 2004) and P. chrysosporium POx (PcPOx; $1.8 \AA$, PDB 4MIF; (Hassan et al. 2013)) show that POx is also the most diverse AA3 member with respect to structural features. In contrast to other AA3 family members, POx is a homotetrameric protein. Each of the two-domain subunits contains one active site with FAD as cofactor, covalently linked to a His. Access to the active site is restricted by a highly mobile active-site loop, which also restricts the activity of the enzyme to monosaccharide substrates. Access to the active sites is furthermore only possible through tunnels from the polypeptide surface to an internal large cavity formed by the four subunits. Each of the subunits carries a small extension termed "head domain" (Fig. 2) of an unknown function; it was speculated that this head domain is involved in oligomerization or in interactions with cell wall-polysaccharides or other proteins (Hallberg et al. 2004). 
The preferred substrate for POx is D-glucose, but in contrast to GOx, POx can utilize both $\alpha$ - and $\beta$-D-glucose (the activity of GOx is restricted to $\alpha$-D-glucose) as well as other monosaccharides including D-galactose, D-xylose, or Dglucono1,5-lactone at relevant rates (Leitner et al. 2001; Pisanelli et al. 2009) for its reductive half-reaction. POx catalyzes the oxidation of these aldopyranoses at position C-2, yielding the corresponding 2-ketoaldoses (2-dehydroaldoses or osones) as products. Some POx can additionally oxidize sugars at C-3, but this activity is typically much lower than oxidation on C-2 (Giffhorn 2000). Catalytic efficiencies for PcPOx and D-glucose are $98.9 \times 10^{3} \mathrm{M}^{-1} \mathrm{~s}^{-1}$ (oxygen/air as saturating substrate, (Pisanelli et al. 2009)). In the oxidative half-reaction, two electrons are transferred from the reduced FAD to $\mathrm{O}_{2}$ forming $\mathrm{H}_{2} \mathrm{O}_{2}$. The oxidative reaction of $\mathrm{POx}$ involves formation of a $\mathrm{C} 4 \mathrm{a}$-hydroperoxyflavin intermediate, which had previously not been detected in other flavindependent oxidases (Wongnate and Chaiyen 2013) but is the typically intermediate for monooxygenases. Apart from oxygen, POx can also utilize alternative electron acceptors including a number of (substituted) quinones and (complexed) metal ions. Interestingly, catalytic efficiencies for some of these electron acceptors are much higher than for molecular oxygen, indicating that these might in fact be the more relevant natural substrates than oxygen $\left(P_{C} \mathrm{POx}, 89.2 \times 10^{3} \mathrm{M}^{-1} \mathrm{~s}^{-1}\right.$ and $11.9 \times 10^{6} \mathrm{M}^{-1} \mathrm{~s}^{-1}$ for oxygen and 1,4-benzoquinone, respectively; in each case D-glucose was the saturating substrate (Pisanelli et al. 2009)).

POx is found in a number of basidiomycetes, associated with membrane-bound vesicles and other membrane structures in the periplasmic space of the fungal hyphae (Daniel et al. 1992) but also extracellularly associated with polysaccharides. In a recent study, Mendes et al. showed that POx sequences can also be found in bacteria with sequence identities of 39-24\% to fungal POx. The majority of these putative bacterial POx sequences occurred in the phylum of Actinobacteria. POx from Arthrobacter siccitolerans is the only characterized bacterial POx so far (Mendes et al. 2016), but POx activity was also proven in medium of the endophytic bacterium Pantoea ananatis when cultivated on rice straw (Ma et al. 2016a) suggesting that POx might be further spread throughout the bacterial domain.

\section{Biological functions of AA3 family members}

Enzymes from the different AA families in the CAZy database do not directly act on polymeric constituents of lignocellulosic material (cellulose, various hemicelluloses, pectin, or lignin) but cooperate with other enzymes and thus help to depolymerise lignocellulose. The AA3 family, as defined by CAZy, consists of FAD-dependent GMC oxidoreductases (Levasseur et al. 2013) that support lignocellulose degradation by reducing low-molecular weight components such as oxygen and quinones as well as metal ions to some extent. The two main products that are formed are $\mathrm{H}_{2} \mathrm{O}_{2}$, resulting from the reduction of oxygen by the oxidases, and hydroquinones from the reduction of quinones by dehydrogenase activities (Fig. 5). Most of the proposed physiological functions that are attributed to AA3 family members can be deduced from these two reactions, and both products (peroxide and hydroquinones) support other enzymes or reactions important for the deconstruction of lignocellulosic material in different ways. Maybe one of the best known of these interactions is the supply of $\mathrm{H}_{2} \mathrm{O}_{2}$ by different oxidases to lignin-modifying peroxidases (LMPs; CAZy auxiliary activities family 2, AA2). Peroxidases employ peroxide as an electron acceptor in the classical peroxidase reaction cycle. Peroxidases in the resting ferric state react with $\mathrm{H}_{2} \mathrm{O}_{2}$ in a two-electron process to generate an intermediate known as compound I (an oxo-ferryl porphyrin cation radical complex), which then oxidizes two substrate molecules in two sequential single-electron abstractions, yielding radical products that are highly reactive. The first lignin-degrading enzymes evolved from a gene encoding a single generic peroxidase, and after gene duplication evolved further into a number of different lignin-degrading class-II peroxidases (Floudas et al. 2012), which play an important role in white-rot as well as in litter-degrading fungi (Lundell et al. 2014).

The role of $\mathrm{H}_{2} \mathrm{O}_{2}$ could even go beyond the activation of peroxidases. Recently, it was shown that LPMOs are activated by $\mathrm{H}_{2} \mathrm{O}_{2}$ (Bissaro et al. 2017), and hence various oxidases formed by LPMO-producing organisms might play an accessory role in the oxidative cleavage of polysaccharides. An AA9 LPMO was co-regulated and co-secreted with an AA3_2 enzyme in the white-rot fungus $P$. cinnabarinus (Miyauchi et al. 2017), and Aspergillus nidulans grown on starch secreted six AA3_2s (together with AA7 glycooligosaccharide oxidases) and starch-active AA13 LPMO. These various enzymes also showed similar secretion patterns (Nekiunaite et al. 2016), which could indicate an interaction between AA3 oxidases and various LPMOs. Several AA3 oxidases are known to be formed intracellularly, including for example GOx (Levasseur et al. 2013). Even these intracellular oxidases might contribute peroxide for extracellular reactions, as it was shown that certain members of the major intrinsic proteins, aquaporins, facilitate the diffusion of hydrogen peroxide through the membrane (Bienert and Chaumont 2014). Genes for these transmembrane proteins are found across all kingdoms of life but were very little studied in fungal organisms, and the function of aquaporins has not been elucidated unequivocally (Tanghe et al. 2006).

Hydrogen peroxide is also essential for a non-enzymatic attack on lignocellulosic material via highly reactive oxygen species formed by Fenton chemistry $\left(\mathrm{Fe}^{2+}+\mathrm{H}_{2} \mathrm{O}_{2}+\mathrm{H}^{+}->\right.$ $\left.\mathrm{Fe}^{3+}+\mathrm{HO}+\mathrm{H}_{2} \mathrm{O}\right)$. This reactivity was first discovered as an attack on cellulose and lignocellulose when adding exogenous 


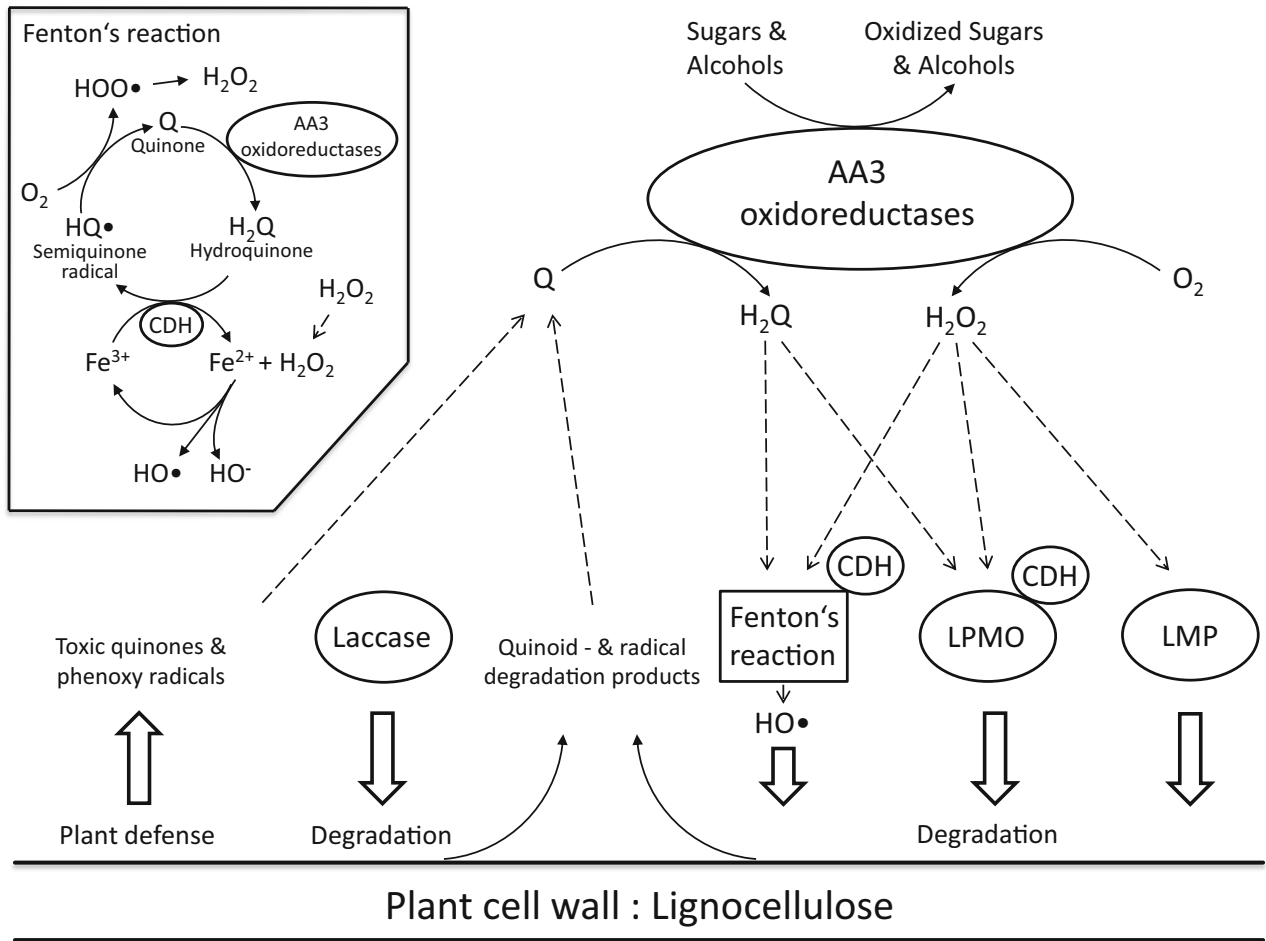

Fig. 5 AA3 enzymes and lignocellulose degradation. This schematic presentation shows possible relevant interactions of different AA3 family oxidoreductases. $\mathrm{H}_{2} \mathrm{O}_{2}$, the reaction product of AA3 oxidases, can fuel lignin-modifying peroxidases (LMP), lytic polysaccharide monooxygenases (LPMO), and drives the Fenton reaction for attack on lignocellulose. Hydroquinones $\left(\mathrm{H}_{2} \mathrm{Q}\right)$, possible reaction products of AA3 dehydrogenase activity, may act as direct electron sources for LPMO and

ferrous iron and hydrogen peroxide (Halliwell 1965; Koenigs 1974), but it is now understood that several enzyme activities contribute to the formation of these two compounds necessary for the Fenton reaction in an attack of brown-rot fungi on wood. Brown-rot fungi apparently lost the ancient manganese peroxidase gene and hence had to adopt a lifestyle different from white-rot organisms (Arantes and Goodell 2014; Lundell et al. 2014). Brown-rot fungi are thought to produce hydrogen peroxide primarily through the oxidation of methanol, which is released through demethylation from lignin substructures, by AA3_3 AOxs (Arantes and Goodell 2014). These are typically found in the genomes of brown-rot organisms, in contrast to the other oxidases implicated in peroxide formation in wood-degrading fungi, AAO and POx (Lundell et al. 2014). Recently, Fenton chemistry was also suggested to play a role in the degradation of rice straw by the endophytic bacterium Pantoea ananatis (Ma et al. 2016a). Strain P. ananatis Sd-1 was found to contain nine genes for AA enzymes, significantly more than the genomes of other $P$. ananatis isolates (Ma et al. 2016b). One of these genes codes for the AA3 4 enzyme POx, and it was suggested that in the bacterial system, POx provides the peroxide needed. $\mathrm{Fe}^{3+}$, which is found and mobilized in wood in concentrations sufficient to support Fenton chemistry, is thought to be reduced by small aromatic can take part in Fenton's reaction cycle. Toxic compounds such as quinones $(\mathrm{Q})$ and radicals emerging from lignin degradation or plant defense can be reduced by AA3 dehydrogenase activity. Cellobiose dehydrogenase $(\mathrm{CDH})$ directly reduces LPMO and is also able to reduce $\mathrm{Fe}^{3+}$ ions for Fenton chemistry. The inset (top left) shows the full Fenton reaction including the reduction of $\mathrm{Fe}^{3+}$ by hydroquinone or $\mathrm{CDH}$

molecules such as 2,5-dimethoxyhydroquinone and related compounds released by brown-rot organisms (or resulting from the attack on lignin), which in turn are oxidized to the corresponding quinones. During the reduction of $\mathrm{Fe}^{3+}$ to $\mathrm{Fe}^{2+}$ by hydroquinones, semiquinone radicals are formed that can react with $\mathrm{O}_{2}$ to give $\mathrm{HOO}^{\circ}$ radicals. These can then dismutate to produce $\mathrm{H}_{2} \mathrm{O}_{2}$ or reduce another $\mathrm{Fe}^{3+}$ (Arantes and Goodell 2014). The hydroquinones driving this redox cycle can regenerate through reduction of the quinones by benzoquinone reductases (CAZy AA6), which are found in brown-rot fungi such as Postia placenta (Martinez et al. 2009). Alternatively, AA3 oxidoreductases (both dehydrogenases and oxidases) might employ these quinones as electron acceptors. GDH, $\mathrm{PDH}$, and POx showed significant activity with various methoxylated quinones (Leitner et al. 2001; Pisanelli et al. 2009; Sygmund et al. 2011), and while PDH and POx are typically not found in brown-rot fungi, other AA3 enzymes might possess comparable catalytic properties. An alternative mechanism for direct iron reduction by an AA3 enzyme involves $\mathrm{CDH}$. $\mathrm{CDH}$ is found in several brown-rot fungi such as Fomitopsis pinicola, Gloeophyllum trabeum, or Serpula lacrymans, yet not all brown-rotters form $\mathrm{CDH}$ (Lundell et al. 2014), so this does not seem to be a universal mechanism. 
A quinone redox cycle comparable to that of brown-rot fungi for the provision of reduced iron was also proposed as one possibility to drive the reaction of LPMO. LPMO relies on the supply of electrons for its catalytic reaction, the oxidative cleavage of polysaccharides. These can be provided, among others, by $\mathrm{CDH}$, as described above, directly by AA3 oxidoreductases (Garajova et al. 2016), or by different quinone compounds (Kracher et al. 2016). These quinone redox mediators can be regenerated and recycled by different AA3s thus fueling the activity of LPMO (Kracher et al. 2016).

The abovementioned reduction of quinones to hydroquinones by AA3s has recently been gaining more attention and could be important for several other functions, in addition to the ones mentioned before. This reduction can be part of a protective mechanism, by which fungi detoxify lignin degradation products or evade plant defense mechanisms. Plants produce toxic quinones during fungal degradation as a defense strategy. Some plants are also found to actively secrete phenoxy radicals to build up lignin as a response to fungal infection in order to physically block off fungal invasionreduction of these radicals by fungal enzyme systems will counteract these plant defense reactions. A possible role of certain AA3s in these proposed mechanisms could be indicated by the expression of $G c \mathrm{GDH}$ in the plant pathogen Glomerella cingulata (anamorph Colletotrichum gloeosporioides) in the presence of quinones rather than under carbon-limited conditions, as shown for $\mathrm{CDH}$ (Zamocky et al. 2006), POx (Vanden Wymelenberg et al. 2009) and PDH (Kittl et al. 2008). Furthermore, GcGDH could reduce phenoxy radicals and thereby might ensure unhindered growth of the fungal hyphae upon plant infection (Sygmund et al. 2011). The phytopathogenic fungus Ustilago maydis secretes a considerable number of putative oxidoreductases when grown on maize bran (Couturier et al. 2012), and the most abundant of these oxidoreductases was identified as an aryl-alcohol oxidase (Couturier et al. 2016). It was suggested that the function of this AA3 2 enzyme is to provide $\mathrm{H}_{2} \mathrm{O}_{2}$ during plant invasion as this compound is thought to contribute to lesion formation and lesion expansion of plant cell walls in the infection mechanism of fungal pathogens (Govrin and Levine 2000).

These proposed functions of AA 3 family members are supported by several recent studies on the secretome and/or the transcriptome of lignocellulose-degrading fungi when cultivated under different conditions. It was shown that $P$. chrysosporium, when grown on cellulose, lignin, or cellulose plus lignin supplemented cultures, secretes a number of AA3 enzymes in addition to numerous CAZymes involved in the decomposition of polysaccharides. The AA3 1 enzyme $\mathrm{CDH}$ was significantly up-regulated under cellulose conditions, whereas various AA3_2, AA3_3, and AA3 4 enzymes, including $\mathrm{AAO}$, GOx-like enzymes, and $\mathrm{AOx}$ and $\mathrm{POx}$ were expressed and up-regulated in cultures with synthetic lignin as the main carbon source (Manavalan et al. 2011). Interestingly, POx was the most abundantly overexpressed protein under these growth conditions, and implies a function in lignin metabolism, which could be by providing $\mathrm{H}_{2} \mathrm{O}_{2}$ to ligninattacking peroxidases but also by reducing quinones released from lignin to less toxic hydroquinones as mentioned above. Similarly, POx was up-regulated in P. chrysosporium when grown under carbon-limited conditions together with AAO and three other unidentified AA3_2 members (Vanden Wymelenberg et al. 2009).

Transcriptome and secretome analyses were used to compare wood decay by a white-rot and a brown-rot fungus, P. chrysosporium and Postia placenta, cultivated on aspen wood (Vanden Wymelenberg et al. 2010). While the former fungus employs a number of extracellular glycoside hydrolases to attack both cellulose and hemicellulose, $P$. placenta secreted an array of hemicellulases and fewer cellulases. Distinct differences were obvious with respect to the expression patterns of oxidoreductase-encoding genes. AOx was detected in both cultures, and it was concluded that methanol oxidation may be an important reaction to provide peroxide (for peroxidases or Fenton's reaction) but also formaldehyde-formate dehydrogenases were up-regulated in both fungi concomitantly, so AOx might also be involved in the metabolism of methanol, which is released from lignin both in white and brown rot decay. In contrast to P. chrysosporium, P. placenta showed significant up-regulation of 1,4-benzoquinone reductase together with an unidentified FAD-dependent oxidoreductase (Pp1122772) and a glucose oxidase-like protein (Ppl128830) (Vanden Wymelenberg et al. 2010). The function of these two latter AA3 enzymes is, however, not known since the corresponding gene products have not been studied with respect to their substrate specificities and oxygen reactivity.

Multigenicity is a feature commonly found in fungal enzyme systems, especially in wood- and litter-degrading fungi, which often have to deal with harmful compounds derived from organic matter degradation, secondary metabolism of antagonists or human activities (Syed et al. 2014). This multigenicity is indicated by the presence of several paralogous genes in an organism as a result of gene duplication events (Taylor 2011), with the purpose of functional compensation upon deficiencies of one of its members (Salame et al. 2013). Moreover, gene duplication events are often followed by gene diversification, and this process is among the most important mechanisms leading to enzyme isoforms with new functionalities (Kilaru et al. 2006; Ramos et al. 2011). Explanations for the existence of multigenic AA family members have been given as functional redundancy, functional diversification including subtle differences in substrate specificity of individual enzymes, or fine-tuning of the gene regulation/expression in order to adapt fungal organisms to the diversity of their natural substrates (Lenfant et al. 2017; 
Levasseur et al. 2013). Examples for this fine-tuning and differences in expression of AA3 genes as a response to different growth conditions and substrates can be found in the literature, e.g., different expression patterns of AA3 members when growing the plant-pathogenic white-rot fungus Heterobasidion irregulare on heartwood and reactionzone wood of Norway spruce (Yakovlev et al. 2013), yet very few studies have looked at the biochemical properties and enzymological differences of individual AA3 family member isoforms from one single organism to better understand this multigenicity (Graf et al. 2017; Mathieu et al. 2016). Plant cell walls are very complex composite structures, and the multigenicity in the AA3 subfamilies might reflect necessities and adaptations to the degradation of these complex substrates.

Interestingly, this apparent need for multiple genes (and hence multiple enzyme activities) varies considerably between fungal species for the different subfamilies of AA3 enzymes. Ferreira et al. compared genes encoding different $\mathrm{H}_{2} \mathrm{O}_{2}$-producing GMC oxidoreductases (and hence AA3 enzymes) in ten genomes of Polyporales (Ferreira et al. 2015). This study again confirmed the multigenicity of different AA3 members to a varying extent-maximally one gene coding for AA3_1 CDH or AA3_4 POx were found in these ten fungal genomes, whereas up to eleven AAO (AA3_2) and six AOx genes (AA3_3) were identified in the genomes of Bjerkandera adusta and Phlebia brevispora, respectively.

To better understand the biological role of AA3 oxidoreductases and their multigenicity in fungal genomes, there is a clear need of more detailed biochemical characterization of various AA3 enzymes and extended studies on the occurrence and expression of AA3 genes in multiple fungal species. A remaining problem for such large-scale genome and lifestyle comparisons is the correct annotation of putative AA3 family enzymes. The challenge stems from the highsequence identity throughout most of the AA3 family as well as the yet very limited set of biochemically characterized sequences/enzymes. Additionally, characterized enzymes are often restricted to a small sequence space, while a much more comprehensive characterization of the AA3 family would be necessary to ensure correct annotation. Lastly a recent study estimates the diversity of fungal species to be between 2.2 and 3.8 million (Hawksworth and Lucking 2017), with only 3-6\% being identified to date. This suggests that currently we are only looking at a fraction of the genetic diversity in fungi and many more AA3 family - and other enzymes are still to be discovered.

Acknowledgements Open access funding provided by Austrian Science Fund (FWF). This work was supported by the Austrian Science Fund (FWF) Doctoral Programme BioToP-Biomolecular Technology of Proteins (FWF W1224) and the European Union's Horizon 2020 research and innovation program (ERC Consolidator Grant OXIDIZE) under grant agreement No 726396. ATA is thankful for a Technology Grant
Southeast Asia scholarship, jointly supported by the ASEAN-European Academic University Network (ASEA-UNINET), the Austrian Federal Ministry of Science, Research and Economy and the Austrian Agency for International Cooperation in Education and Research (OeAD-GmbH).

\section{Compliance with ethical standards}

Conflict of interest The authors declare that they have no conflict of interest.

Open Access This article is distributed under the terms of the Creative Commons Attribution 4.0 International License (http:// creativecommons.org/licenses/by/4.0/), which permits unrestricted use, distribution, and reproduction in any medium, provided you give appropriate credit to the original author(s) and the source, provide a link to the Creative Commons license, and indicate if changes were made.

\section{References}

Albrecht M, Lengauer T (2003) Pyranose oxidase identified as a member of the GMC oxidoreductase family. Bioinformatics 19(10):1216 1220. https://doi.org/10.1093/bioinformatics/btg140

Ander P (1994) The cellobiose oxidizing enzymes CBQ and CbO as related to lignin and cellulose degradation-a review. FEMS Microbiol Rev 13:297-312

Arantes V, Goodell B (2014) Current understanding of brown-rot fungal biodegradation mechanisms: a review. ACS Symp Ser 1158:3-21

Ashin VV, Trotsenko YA (1998) Formation and distribution of modified FAD between isozymes of alcohol oxidase in the methylotrophic yeast Pichia methanolica. Biochemistry (Mosc) 63:1407-1413

Ayers AR, Ayers SB, Eriksson KE (1978) Cellobiose oxidase, purification and partial characterization of a hemoprotein from Sporotrichum pulverulentum. Eur J Biochem 90(1):171-181. https://doi.org/10.1111/j.1432-1033.1978.tb12588.x

Bannwarth M, Bastian S, Heckmann-Pohl D, Giffhorn F, Schulz GE (2004) Crystal structure of pyranose 2-oxidase from the white-rot fungus Peniophora sp. Biochemistry 43(37):11683-11690. https:// doi.org/10.1021/bi048609q

Bao W, Usha SN, Renganathan V (1993) Purification and characterization of cellobiose dehydrogenase, a novel extracellular hemoflavoenzyme from the white-rot fungus Phanerochaete chrysosporium. Arch Biochem Biophys 300(2):705-713. https:// doi.org/10.1006/abbi.1993.1098

Beeson WT, Vu VV, Span EA, Phillips CM, Marletta MA (2015) Cellulose degradation by polysaccharide monooxygenases. Annu Rev Biochem 84(1):923-946. https://doi.org/10.1146/annurevbiochem-060614-034439

Bienert GP, Chaumont F (2014) Aquaporin-facilitated transmembrane diffusion of hydrogen peroxide. Biochim Biophys Acta 1840(5): 1596-1604. https://doi.org/10.1016/j.bbagen.2013.09.017

Bissaro B, Rohr AK, Müller G, Chylenski P, Skaugen M, Forsberg Z, Horn SJ, Vaaje-Kolstad G, Eijsink VGH (2017) Oxidative cleavage of polysaccharides by monocopper enzymes depends on $\mathrm{H}_{2} \mathrm{O}_{2}$. Nat Chem Biol 13(10):1123-1128. https://doi.org/10.1038/nchembio. 2470

Bourbonnais R, Paice MG (1988) Veratryl alcohol oxidases from the lignin-degrading basidiomycete Pleurotus sajor-caju. Biochem J 255(2):445-450. https://doi.org/10.1042/bj2550445

Cavener DR (1992) GMC oxidoreductases. A newly defined family of homologous proteins with diverse catalytic activities. J Mol Biol 223(3):811-814

Couturier M, Navarro D, Olive C, Chevret D, Haon M, Favel A, LesageMeessen L, Henrissat B, Coutinho PM, Berrin JG (2012) Post- 
genomic analyses of fungal lignocellulosic biomass degradation reveal the unexpected potential of the plant pathogen Ustilago maydis. BMC Genomics 13(1):57. https://doi.org/10.1186/1471-2164-13-57

Couturier M, Mathieu Y, Li A, Navarro D, Drula E, Haon M, Grisel S, Ludwig R, Berrin JG (2016) Characterization of a new aryl-alcohol oxidase secreted by the phytopathogenic fungus Ustilago maydis. Appl Microbiol Biotechnol 100(2):697-706. https://doi.org/10. 1007/s00253-015-7021-3

Daniel G, Volc J, Kubatova E, Nilsson T (1992) Ultrastructural and immunocytochemical studies on the $\mathrm{H}_{2} \mathrm{O}_{2}$-producing enzyme pyranose oxidase in Phanerochaete chrysosporium grown under liquid culture conditions. Appl Environ Microbiol 58: 3667-3676.

Daniel G, Volc J, Filonová L, Plihal O, Kubátová E, Halada P (2007) Characteristics of Gloeophyllum trabeum alcohol oxidase, an extracellular source of $\mathrm{H}_{2} \mathrm{O}_{2}$ in brown rot decay of wood. Appl Environ Microbiol 73(19):6241-6253. https://doi.org/10.1128/AEM.0097707

de Oliveira BV, Teixeira GS, Reis O, Barau JG, Teixeira PJ, do Rio MC, Domingues RR, Meinhardt LW, Paes Leme AF, Rincones J, Pereira GA (2012) A potential role for an extracellular methanol oxidase secreted by Moniliophthora perniciosa in Witches' broom disease in cacao. Fungal Genet Biol 49(11):922-932. https://doi.org/10.1016/j. fgb.2012.09.001

Fernández IS, Ruíz-Dueñas FJ, Santillana E, Ferreira P, Martínez MJ, Martínez AT, Romero A (2009) Novel structural features in the GMC family of oxidoreductases revealed by the crystal structure of fungal aryl-alcohol oxidase. Acta Crystallogr D Biol Crystallogr 65(11):1196-1205. https://doi.org/10.1107/S0907444909035860

Ferreira P, Ruiz-Duenas FJ, Martínez MJ, van Berkel WJ, Martínez AT (2006) Site-directed mutagenesis of selected residues at the active site of aryl-alcohol oxidase, an $\mathrm{H}_{2} \mathrm{O}_{2}$-producing ligninolytic enzyme. FEBS J 273(21):4878-4888. https://doi.org/10.1111/j.17424658.2006.05488.x

Ferreira P, Carro J, Serrano A, Martínez AT (2015) A survey of genes encoding $\mathrm{H}_{2} \mathrm{O}_{2}$-producing GMC oxidoreductases in 10 Polyporales genomes. Mycologia 107(6):1105-1119. https://doi.org/10.3852/ $15-027$

Floudas D, Binder M, Riley R, Barry K, Blanchette RA, Henrissat B, Martínez AT, Otillar R, Spatafora JW, Yadav JS, Aerts A, Benoit I, Boyd A, Carlson A, Copeland A, Coutinho PM, de Vries RP, Ferreira P, Findley K, Foster B, Gaskell J, Glotzer D, Górecki P, Heitman J, Hesse C, Hori C, Igarashi K, Jurgens JA, Kallen N, Kersten P, Kohler A, Kües U, Kumar TK, Kuo A, LaButti K, Larrondo LF, Lindquist E, Ling A, Lombard V, Lucas S, Lundell T, Martin R, McLaughlin DJ, Morgenstern I, Morin E, Murat C, Nagy LG, Nolan M, Ohm RA, Patyshakuliyeva A, Rokas A, Ruiz-Dueñas FJ, Sabat G, Salamov A, Samejima M, Schmutz J, Slot JC, St John F, Stenlid J, Sun H, Sun S, Syed K, Tsang A, Wiebenga A, Young D, Pisabarro A, Eastwood DC, Martin F, Cullen D, Grigoriev IV, Hibbett DS (2012) The Paleozoic origin of enzymatic lignin decomposition reconstructed from 31 fungal genomes. Science 336(6089):1715-1719. https://doi.org/10.1126/ science. 1221748

Garajova S, Mathieu Y, Beccia MR, Bennati-Granier C, Biaso F, Fanuel M, Ropartz D, Guigliarelli B, Record E, Rogniaux H, Henrissat B, Berrin JG (2016) Single-domain flavoenzymes trigger lytic polysaccharide monooxygenases for oxidative degradation of cellulose. Sci Rep 6:28276. https://doi.org/10.1038/srep28276

Giffhorn F (2000) Fungal pyranose oxidases: occurrence, properties and biotechnical applications in carbohydrate chemistry. Appl Microbiol Biotechnol 54:727-740

Gonaus C, Kittl R, Sygmund C, Haltrich D, Peterbauer C (2016) Transcription analysis of pyranose dehydrogenase from the basidiomycete Agaricus bisporus and characterization of the recombinantly expressed enzyme. Protein Expr Purif 119:36-44. https://doi.org/10. 1016/j.pep.2015.11.003
Govrin EM, Levine A (2000) The hypersensitive response facilitates plant infection by the necrotrophic pathogen Botrytis cinerea. Curr Biol 10:751-757

Graf MM, Sucharitakul J, Bren U, Chu DB, Koellensperger G, Hann S, Furtmüller PG, Obinger C, Peterbauer CK, Oostenbrink C, Chaiyen P, Haltrich D (2015) Reaction of pyranose dehydrogenase from Agaricus meleagris with its carbohydrate substrates. FEBS J 282: 4218-4241. https://doi.org/10.1111/febs.13417

Graf MM, Weber S, Kracher D, Kittl R, Sygmund C, Ludwig R, Peterbauer C, Haltrich D (2017) Characterization of three pyranose dehydrogenase isoforms from the litter-decomposing basidiomycete Leucoagaricus meleagris (syn. Agaricus meleagris). Appl Microbiol Biotechnol 101:2879-2891. https://doi.org/10.1007/ s00253-016-8051-1

Guillén F, Martínez AT, Martínez MJ (1990) Production of hydrogen peroxide by aryl-alcohol oxidase from the ligninolytic fungus Pleurotus eryngii. Appl Microbiol Biotechnol 32:465-469

Guillén F, Martínez AT, Martínez MJ (1992) Substrate specificity and properties of the aryl-alcohol oxidase from the ligninolytic fungus Pleurotus eryngii. Eur J Biochem 209:603-611

Guindon S, Dufayard JF, Lefort V, Anisimova M, Hordijk W, Gascuel O (2010) New algorithms and methods to estimate maximumlikelihood phylogenies: assessing the performance of PhyML 3.0. Syst Biol 59:307-321. https://doi.org/10.1093/sysbio/syq010

Gvozdev AR, Tukhvatullin IA, Gvozdev RI (2012) Quinone-dependent alcohol dehydrogenases and FAD-dependent alcohol oxidases. Biochemistry (Mosc) 77:843-856. https://doi.org/10.1134/ S0006297912080056

Hallberg BM, Bergfors T, Bäckbro K, Pettersson G, Henriksson G, Divne C (2000) A new scaffold for binding haem in the cytochrome domain of the extracellular flavocytochrome cellobiose dehydrogenase. Structure 8:79-88

Hallberg BM, Henriksson G, Pettersson G, Divne C (2002) Crystal structure of the flavoprotein domain of the extracellular flavocytochrome cellobiose dehydrogenase. J Mol Biol 315:421-434

Hallberg BM, Leitner C, Haltrich D, Divne C (2004) Crystal structure of the $270 \mathrm{kDa}$ homotetrameric lignin-degrading enzyme pyranose 2oxidase. J Mol Biol 341:781-796

Halliwell G (1965) Catalytic decomposition of cellulose under biological conditions. Biochem J 95:35-40

Harada H, Onoda A, Uchihashi T, Watanabe H, Sunagawa N, Samejima M, Igarashi K, Hayashi T (2017) Interdomain flip-flop motion visualized in flavocytochrome cellobiose dehydrogenase using highspeed atomic force microscopy during catalysis. Chem Sci 8: 6561-6565. https://doi.org/10.1039/c7sc01672g

Harreither W, Sygmund C, Augustin M, Narciso M, Rabinovich ML, Gorton L, Haltrich D, Ludwig R (2011) Catalytic properties and classification of cellobiose dehydrogenases from ascomycetes. Appl Environ Microbiol 77:1804-1815. https://doi.org/10.1128/ AEM.02052-10

Hassan N, Tan TC, Spadiut O, Pisanelli I, Fusco L, Haltrich D, Peterbauer CK, Divne C (2013) Crystal structures of Phanerochaete chrysosporium pyranose 2-oxidase suggest that the $\mathrm{N}$-terminus acts as a propeptide that assists in homotetramer assembly. FEBS Open Bio 3:496-504. https://doi.org/10.1016/j.fob.2013.10.010

Hawksworth DL, Lucking R (2017) Fungal diversity revisited: 2.2 to 3.8 million species. Microbiol Spectr 5(4). https://doi.org/10.1128/ microbiolspec.FUNK-0052-2016

Hecht HJ, Kalisz HM, Hendle J, Schmid RD, Schomburg D (1993) Crystal structure of glucose oxidase from Aspergillus niger refined at $2.3 \AA$ resolution. J Mol Biol 229:153-172

Henriksson G, Pettersson G, Johansson G, Ruiz A, Uzcategui E (1991) Cellobiose oxidase from Phanerochaete chrysosporium can be cleaved by papain into two domains. Eur J Biochem 196:101-106

Hernandez-Ortega A, Ferreira P, Martínez AT (2012) Fungal aryl-alcohol oxidase: a peroxide-producing flavoenzyme involved in lignin 
degradation. Appl Microbiol Biotechnol 93:1395-1410. https://doi. org/10.1007/s00253-011-3836-8

Hyde SM, Wood PM (1997) A mechanism for production of hydroxyl radicals by the brown-rot fungus Coniophora puteana: Fe(III) reduction by cellobiose dehydrogenase and Fe(II) oxidation at a distance from the hyphae. Microbiology 143:259-266

Iida K, Cox-Foster DL, Yang X, Ko WY, Cavener DR (2007) Expansion and evolution of insect GMC oxidoreductases. BMC Evol Biol 7: 7.5. https://doi.org/10.1186/1471-2148-7-75

Janssen FW, Ruelius HW (1968) Carbohydrate oxidase, a novel enzyme from Polyporus obtusus. II. Specificity and characterization of reaction products. Biochim Biophys Acta 167:501-510

Janssen FW, Kerwin RM, Ruelius HW (1965) Alcohol oxidase, a novel enzyme from a basidiomycete. Biochem Biophys Res Commun 20: $630-634$

Kadek A, Kavan D, Marcoux J, Stojko J, Felice AK, Cianferani S, Ludwig R, Halada P, Man P (2017) Interdomain electron transfer in cellobiose dehydrogenase is governed by surface electrostatics. Biochim Biophys Acta 1861:157-167. https://doi.org/10.1016/j. bbagen.2016.11.016

Kiess M, Hecht HJ, Kalisz HM (1998) Glucose oxidase from Penicillium amagasakiense. Primary structure and comparison with other glucose-methanol-choline (GMC) oxidoreductases. Eur J Biochem 252:90-99

Kilaru S, Hoegger PJ, Kües U (2006) The laccase multi-gene family in Coprinopsis cinerea has seventeen different members that divide into two distinct subfamilies. Curr Genet 50:45-60. https://doi.org/ 10.1007/s00294-006-0074-1

Kittl R, Sygmund C, Halada P, Volc J, Divne C, Haltrich D, Peterbauer CK (2008) Molecular cloning of three pyranose dehydrogenaseencoding genes from Agaricus meleagris and analysis of their expression by real-time RT-PCR. Curr Genet 53:117-127. https://doi. org/10.1007/s00294-007-0171-9

Koch C, Neumann P, Valerius O, Feussner I, Ficner R (2016) Crystal structure of alcohol oxidase from Pichia pastoris. PLoS One 11: e0149846. https://doi.org/10.1371/journal.pone.0149846

Koenigs JW (1974) Hydrogen peroxide and iron: a proposed system for decomposition of wood by brown-rot basidiomycetes. Wood Fiber Sci 6:66-80

Kracher D, Ludwig R (2016) Cellobiose dehydrogenase: an essential enzyme for lignocellulose degradation in nature - a review. Die Bodenkultur J Land Manag Food Environ 67:145-163

Kracher D, Scheiblbrandner S, Felice AK, Breslmayr E, Preims M, Ludwicka K, Haltrich D, Eijsink VG, Ludwig R (2016) Extracellular electron transfer systems fuel cellulose oxidative degradation. Science 352:1098-1101. https://doi.org/10.1126/science. aaf3165

Kujawa M, Volc J, Halada P, Sedmera P, Divne C, Sygmund C, Leitner C, Peterbauer C, Haltrich D (2007) Properties of pyranose dehydrogenase purified from the litter-degrading fungus Agaricus xanthoderma. FEBS J 274:879-894

Kumar S, Stecher G, Tamura K (2016) MEGA7: molecular evolutionary genetics analysis version 7.0 for bigger datasets. Mol Biol Evol 33: 1870-1874. https://doi.org/10.1093/molbev/msw054

Leitner C, Volc J, Haltrich D (2001) Purification and characterization of pyranose oxidase from the white-rot fungus Trametes multicolor. Appl Environ Microbiol 67:3636-3644

Lenfant N, Hainaut M, Terrapon N, Drula E, Lombard V, Henrissat B (2017) A bioinformatics analysis of 3400 lytic polysaccharide oxidases from family AA9. Carbohydr Res 448:166-174. https://doi. org/10.1016/j.carres.2017.04.012

Levasseur A, Drula E, Lombard V, Coutinho PM, Henrissat B (2013) Expansion of the enzymatic repertoire of the CAZy database to integrate auxiliary redox enzymes. Biotechnol Biofuels 6:41. https://doi.org/10.1186/1754-6834-6-41
Levasseur A, Lomascolo A, Chabrol O, Ruiz-Dueñas FJ, Boukhris-Uzan E, Piumi F, Kües U, Ram AF, Murat C, Haon M, Benoit I, Arfi Y, Chevret D, Drula E, Kwon MJ, Gouret P, Lesage-Meessen L, Lombard V, Mariette J, Noirot C, Park J, Patyshakuliyeva A, Sigoillot JC, Wiebenga A, Wösten HA, Martin F, Coutinho PM, de Vries RP, Martínez AT, Klopp C, Pontarotti P, Henrissat B, Record E (2014) The genome of the white-rot fungus Pycnoporus cinnabarinus: a basidiomycete model with a versatile arsenal for lignocellulosic biomass breakdown. BMC Genomics 15:486. https://doi.org/10.1186/1471-2164-15-486

Lombard V, Golaconda Ramulu H, Drula E, Coutinho PM, Henrissat B (2014) The carbohydrate-active enzymes database (CAZy) in 2013. Nucleic Acids Res 42:D490-D495. https://doi.org/10.1093/nar/ gkt1178

Lundell TK, Mäkelä M-R, de Vries RP, Hildén KS (2014) Genomics, lifestyles and future prospects of wood-decay and litterdecomposing basidiomycota. In: Martin FM (ed) Fungi. Advances in Botanical Research, vol 70. Elsevier, London, pp 329-370

Ma J, Zhang K, Huang M, Hector SB, Liu B, Tong C, Liu Q, Zeng J, Gao Y, Xu T, Liu Y, Liu X, Zhu Y (2016a) Involvement of Fenton chemistry in rice straw degradation by the lignocellulolytic bacterium Pantoea ananatis Sd-1. Biotechnol Biofuels 9:211. https://doi. org/10.1186/s13068-016-0623-x

Ma J, Zhang K, Liao H, Hector SB, Shi X, Li J, Liu B, Xu T, Tong C, Liu X, Zhu Y (2016b) Genomic and secretomic insight into lignocellulolytic system of an endophytic bacterium Pantoea ananatis Sd-1. Biotechnol Biofuels 9:25. https://doi.org/10.1186/ s13068-016-0439-8

Manavalan A, Adav SS, Sze SK (2011) iTRAQ-based quantitative secretome analysis of Phanerochaete chrysosporium. J Proteome 75:642-654. https://doi.org/10.1016/j.jprot.2011.09.001

Martinez D, Challacombe J, Morgenstern I, Hibbett D, Schmoll M, Kubicek CP, Ferreira P, Ruiz-Duenas FJ, Martinez AT, Kersten P, Hammel KE, Vanden Wymelenberg A, Gaskell J, Lindquist E, Sabat G, Bondurant SS, Larrondo LF, Canessa P, Vicuna R, Yadav J, Doddapaneni H, Subramanian V, Pisabarro AG, Lavin JL, Oguiza JA, Master E, Henrissat B, Coutinho PM, Harris P, Magnuson JK, Baker SE, Bruno K, Kenealy W, Hoegger PJ, Kües U, Ramaiya P, Lucas S, Salamov A, Shapiro H, Tu H, Chee CL, Misra M, Xie G, Teter S, Yaver D, James T, Mokrejs M, Pospisek M, Grigoriev IV, Brettin T, Rokhsar D, Berka R, Cullen D (2009) Genome, transcriptome, and secretome analysis of wood decay fungus Postia placenta supports unique mechanisms of lignocellulose conversion. Proc Natl Acad Sci U S A 106:1954-1959. https://doi.org/10.1073/ pnas.0809575106

Mathieu Y, Piumi F, Valli R, Aramburu JC, Ferreira P, Faulds CB, Record E (2016) Activities of secreted aryl alcohol quinone oxidoreductases from Pycnoporus cinnabarinus provide insights into fungal degradation of plant biomass. Appl Environ Microbiol 82:2411-2423. https://doi.org/10.1128/AEM.03761-15

Matsumura H, Umezawa K, Takeda K, Sugimoto N, Ishida T, Samejima M, Ohno H, Yoshida M, Igarashi K, Nakamura N (2014) Discovery of a eukaryotic pyrroloquinoline quinone-dependent oxidoreductase belonging to a new auxiliary activity family in the database of carbohydrate-active enzymes. PLoS One 9:e104851. https://doi. org/10.1371/journal.pone.0104851

Mattevi A (2006) To be or not to be an oxidase: challenging the oxygen reactivity of flavoenzymes. Trends Biochem Sci 31:276-283. https://doi.org/10.1016/j.tibs.2006.03.003

Mendes S, Banha C, Madeira J, Santos D, Miranda V, Manzanera M, Ventura MR, van Berkel WJ, Martins LO (2016) Characterization of a bacterial pyranose 2-oxidase from Arthrobacter siccitolerans. J Mol Catal B Enzym 133:S34-S43

Miyauchi S, Navarro D, Grisel S, Chevret D, Berrin JG, Rosso MN (2017) The integrative omics of white-rot fungus Pycnoporus coccineus reveals co-regulated CAZymes for orchestrated 
lignocellulose breakdown. PLoS One 12:e0175528. https://doi.org/ 10.1371/journal.pone.0175528

Mori K, Nakajima M, Kojima K, Murakami K, Ferri S, Sode K (2011) Screening of Aspergillus-derived FAD-glucose dehydrogenases from fungal genome database. Biotechnol Lett 33:2255-2263. https://doi.org/10.1007/s10529-011-0694-5

Müller D (1928) Studien über ein neues Enzym Glucoseoxydase. I. Biochem Z 199:136-170

Nekiunaite L, Arntzen MO, Svensson B, Vaaje-Kolstad G, Abou Hachem M (2016) Lytic polysaccharide monooxygenases and other oxidative enzymes are abundantly secreted by Aspergillus nidulans grown on different starches. Biotechnol Biofuels 9:187. https://doi.org/10. 1186/s13068-016-0604-0

Ogura Y, Nagahisa M (1937) Untersuchungen über die Atmung und die Dehydrasesysteme von Aspergillus oryzae. Bot Mag (Tokyo) 51: 597-612

Ozimek P, Veenhuis M, van der Klei IJ (2005) Alcohol oxidase: a complex peroxisomal, oligomeric flavoprotein. FEMS Yeast Res 5:975983. https://doi.org/10.1016/j.femsyr.2005.06.005

Peterbauer CK, Volc J (2010) Pyranose dehydrogenases: biochemical features and perspectives of technological applications. Appl Microbiol Biotechnol 85:837-848. https://doi.org/10.1007/s00253009-2226-y

Phillips CM, Beeson WT, Cate JH, Marletta MA (2011) Cellobiose dehydrogenase and a copper-dependent polysaccharide monooxygenase potentiate cellulose degradation by Neurospora crassa. ACS Chem Biol 6:1399-1406. https://doi.org/10.1021/ cb200351y

Pisanelli I, Kujawa M, Spadiut O, Kittl R, Halada P, Volc J, Mozuch MD, Kersten P, Haltrich D, Peterbauer C (2009) Pyranose 2-oxidase from Phanerochaete chrysosporium - expression in E. coli and biochemical characterization. J Biotechnol 142:97-106. https://doi.org/10. 1016/j.jbiotec.2009.03.019

Piumi F, Levasseur A, Navarro D, Zhou S, Mathieu Y, Ropartz D, Ludwig R, Faulds CB, Record E (2014) A novel glucose dehydrogenase from the white-rot fungus Pycnoporus cinnabarinus: production in Aspergillus niger and physicochemical characterization of the recombinant enzyme. Appl Microbiol Biotechnol 98:1010510118. https://doi.org/10.1007/s00253-014-5891-4

Ramos JA, Barends S, Verhaert RM, de Graaff LH (2011) The Aspergillus niger multicopper oxidase family: analysis and overexpression of laccase-like encoding genes. Microb Cell Factories 10: 78. https://doi.org/10.1186/1475-2859-10-78

Roth JP, Klinman JP (2003) Catalysis of electron transfer during activation of $\mathrm{O}_{2}$ by the flavoprotein glucose oxidase. Proc Natl Acad Sci U S A 100:62-67. https://doi.org/10.1073/pnas.252644599

Salame TM, Knop D, Levinson D, Yarden O, Hadar Y (2013) Redundancy among manganese peroxidases in Pleurotus ostreatus. Appl Environ Microbiol 79:2405-2415. https://doi.org/10.1128/ AEM.03849-12

Sannia G, Limongi P, Cocca E, Buonocore F, Nitti G, Giardina P (1991) Purification and characterization of a veratryl alcohol oxidase enzyme from the lignin degrading basidiomycete Pleurotus ostreatus. Biochim Biophys Acta 1073:114-119

Sode K, Loew N, Ohnishi Y, Tsuruta H, Mori K, Kojima K, Tsugawa W, LaBelle JT, Klonoff DC (2017) Novel fungal FAD glucose dehydrogenase derived from Aspergillus niger for glucose enzyme sensor strips. Biosens Bioelectron 87:305-311. https://doi.org/10.1016/j. bios.2016.08.053

Sun W, Shen YH, Yang WJ, Cao YF, Xiang ZH, Zhang Z (2012) Expansion of the silkworm GMC oxidoreductase genes is associated with immunity. Insect Biochem Mol Biol 42:935-945. https://doi. org/10.1016/j.ibmb.2012.09.006

Syed K, Shale K, Pagadala NS, Tuszynski J (2014) Systematic identification and evolutionary analysis of catalytically versatile cytochrome P450 monooxygenase families enriched in model basidiomycete fungi. PLoS One 9:e86683. https://doi.org/10.1371/ journal.pone. 0086683

Sygmund C, Kittl R, Volc J, Halada P, Kubátová E, Haltrich D, Peterbauer CK (2008) Characterization of pyranose dehydrogenase from Agaricus meleagris and its application in the C-2 specific conversion of D-galactose. J Biotechnol 133:334-342. https://doi.org/ 10.1016/j.jbiotec.2007.10.013

Sygmund C, Klausberger M, Felice AK, Ludwig R (2011) Reduction of quinones and phenoxy radicals by extracellular glucose dehydrogenase from Glomerella cingulata suggests a role in plant pathogenicity. Microbiology 157:3203-3212. https://doi.org/10.1099/mic.0. 051904-0

Takeda K, Matsumura H, Ishida T, Samejima M, Ohno H, Yoshida M, Igarashi K, Nakamura N (2015) Characterization of a novel PQQdependent quinohemoprotein pyranose dehydrogenase from Coprinopsis cinerea classified into auxiliary activities family 12 in carbohydrate-active enzymes. PLoS One 10:e0115722. https://doi. org/10.1371/journal.pone.0115722

Tan TC, Spadiut O, Wongnate T, Sucharitakul J, Krondorfer I, Sygmund C, Haltrich D, Chaiyen P, Peterbauer CK, Divne C (2013) The $1.6 \AA$ crystal structure of pyranose dehydrogenase from Agaricus meleagris rationalizes substrate specificity and reveals a flavin intermediate. PLoS One 8(1):e53567. https://doi.org/10.1371/journal. pone. 0053567

Tan TC, Kracher D, Gandini R, Sygmund C, Kittl R, Haltrich D, Hallberg BM, Ludwig R, Divne C (2015) Structural basis for cellobiose dehydrogenase action during oxidative cellulose degradation. Nat Commun 6:7542. https://doi.org/10.1038/ncomms8542

Tanghe A, Van Dijck P, Thevelein JM (2006) Why do microorganisms have aquaporins? Trends Microbiol 14:78-85. https://doi.org/10. 1016/j.tim.2005.12.001

Taylor JW (2011) The poetry of mycological accomplishment and challenge. Fungal Biol Rev 25:3-13

Vanden Wymelenberg A, Gaskell J, Mozuch M, Kersten P, Sabat G, Martinez D, Cullen D (2009) Transcriptome and secretome analyses of Phanerochaete chrysosporium reveal complex patterns of gene expression. Appl Environ Microbiol 75:4058-4068. https://doi.org/ 10.1128/AEM.00314-09

Vanden Wymelenberg A, Gaskell J, Mozuch M, Sabat G, Ralph J, Skyba O, Mansfield SD, Blanchette RA, Martinez D, Grigoriev I, Kersten PJ, Cullen D (2010) Comparative transcriptome and secretome analysis of wood decay fungi Postia placenta and Phanerochaete chrysosporium. Appl Environ Microbiol 76:3599-3610. https:// doi.org/10.1128/AEM.00058-10

Volc J, Kubátová E, Wood DA, Daniel G (1997) Pyranose 2-dehydrogenase, a novel sugar oxidoreductase from the basidiomycete fungus Agaricus bisporus. Arch Microbiol 167:119-125

Volc J, Kubátová E, Daniel G, Sedmera P, Haltrich D (2001) Screening of basidiomycete fungi for the quinone-dependent sugar C-2/C-3 oxidoreductase, pyranose dehydrogenase, and properties of the enzyme from Macrolepiota rhacodes. Arch Microbiol 176:178-186

Vonck J, Parcej DN, Mills DJ (2016) Structure of alcohol oxidase from Pichia pastoris by cryo-electron microscopy. PLoS One 11: e0159476. https://doi.org/10.1371/journal.pone.0159476

Wallace IM, O'Sullivan O, Higgins DG, Notredame C (2006) M-Coffee: combining multiple sequence alignment methods with T-offee. Nucleic Acids Res 34:1692-1699. https://doi.org/10.1093/nar/ gk1091

Westermark U, Eriksson KE (1974) Cellobiose: quinone oxidoreductase, a new wood-degrading enzyme from white-rot fungi. Acta Chem Scand B28:209-214

Whelan S, Goldman N (2001) A general empirical model of protein evolution derived from multiple protein families using a maximum-likelihood approach. Mol Biol Evol 18:691-699

Wohlfahrt G, Witt S, Hendle J, Schomburg D, Kalisz HM, Hecht HJ (1999) 1.8 and $1.9 \AA$ resolution structures of the Penicillium 
amagasakiense and Aspergillus niger glucose oxidases as a basis for modelling substrate complexes. Acta Crystallogr D Biol Crystallogr 55:969-977

Wongnate T, Chaiyen P (2013) The substrate oxidation mechanism of pyranose 2-oxidase and other related enzymes in the glucosemethanol-choline superfamily. FEBS J 280:3009-3027. https://doi. org/10.1111/febs. 12280

Yakovlev IA, Hietala AM, Courty PE, Lundell T, Solheim H, Fossdal CG (2013) Genes associated with lignin degradation in the polyphagous white-rot pathogen Heterobasidion irregulare show substratespecific regulation. Fungal Genet Biol 56:17-24. https://doi.org/ 10.1016/j.fgb.2013.04.011

Yoshida H, Sakai G, Mori K, Kojima K, Kamitori S, Sode K (2015) Structural analysis of fungus-derived FAD glucose dehydrogenase. Sci Rep 5:13498. https://doi.org/10.1038/srep13498
Zamocky M, Hallberg M, Ludwig R, Divne C, Haltrich D (2004) Ancestral gene fusion in cellobiose dehydrogenases reflects a specific evolution of GMC oxidoreductases in fungi. Gene 338:1-14

Zamocky M, Ludwig R, Peterbauer C, Hallberg BM, Divne C, Nicholls P, Haltrich D (2006) Cellobiose dehydrogenase - a flavocytochrome from wood-degrading, phytopathogenic and saprotropic fungi. Curr Protein Pept Sci 7:255-280

Zamocky M, Schumann C, Sygmund C, O'Callaghan J, Dobson AD, Ludwig R, Haltrich D, Peterbauer CK (2008) Cloning, sequence analysis and heterologous expression in Pichia pastoris of a gene encoding a thermostable cellobiose dehydrogenase from Myriococcum thermophilum. Protein Expr Purif 59:258-265. https://doi.org/10.1016/j.pep.2008.02.007 